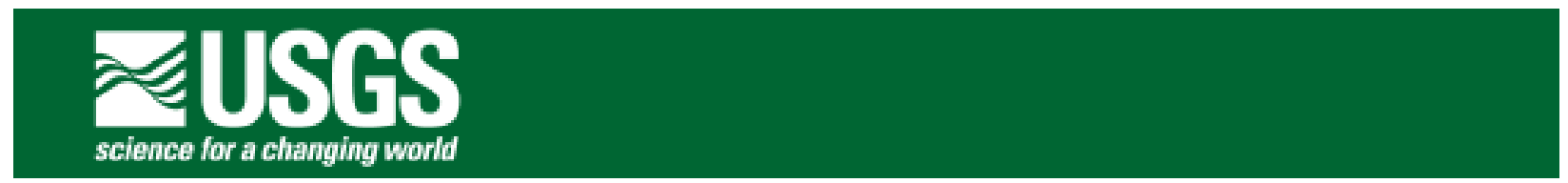

\title{
Magnetotelluric Study of the Pahute Mesa and \\ Oasis Valley Regions, Nye County, Nevada
}

By Clifford J. Schenkel ${ }^{1}$, Thomas G. Hildenbrand ${ }^{1}$, and Gary L. Dixon ${ }^{2}$

Open-File Report 99-355

Version 1.0

http://geopubs.wr.usgs.gov/open-file/of99-355

Prepared in cooperation with the

\section{U.S. DEPARTMENT OF ENERGY NEVADA OPERATIONS OFFICE}

(Interagency Agreement DE-AI08-96NV11967)

1999

This report is preliminary and has not been reviewed for conformity with U.S. Geological Survey editorial standards or with the North American Stratigraphic Code. Use of trade, firm, or product names is for descriptive purposes only and does not imply endorsement by the U.S. Government.

\section{U.S. DEPARTMENT OF THE INTERIOR U.S. GEOLOGICAL SURVEY}

\footnotetext{
${ }^{1}$ Menlo Park, California 94025

${ }^{2}$ Las Vegas, Nevada 89119
} 


\section{Table of Contents}

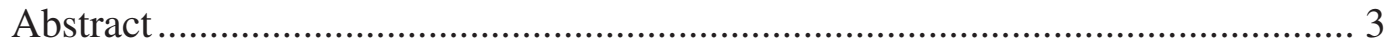

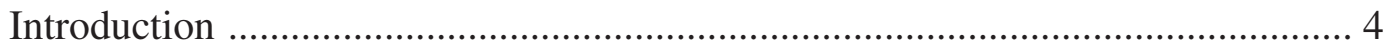

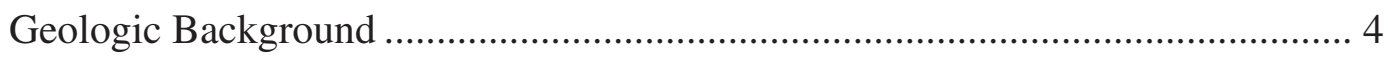

Magnetotelluric Method ............................................................................. 6

Electrical Properties ....................................................................................... 7

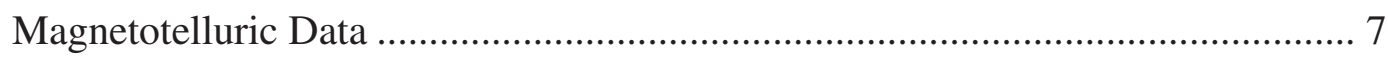

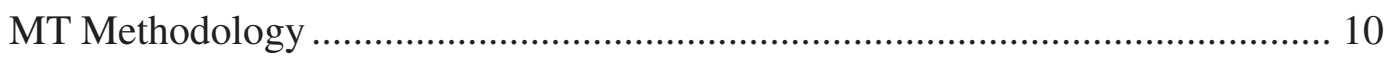

Pahute Mesa MT Profiles ..................................................................... 11

Oasis Valley MT Profiles ...................................................................... 19

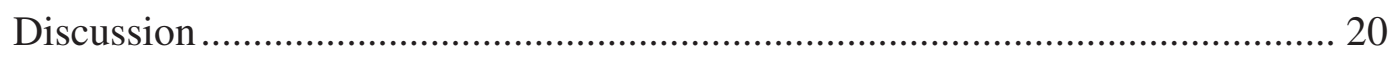

Thirsty Canyon Fault Zone .............................................................. 22

Oasis Valley Basin .................................................................................... 23

Buckboard Mesa Lineament ................................................................. 23

Hydrologic Implications .......................................................................... 24

Thirsty Canyon Fault Zone ............................................................... 24

Buckboard Mesa Lineament ................................................................... 25

Oasis Valley Basin ....................................................................... 26

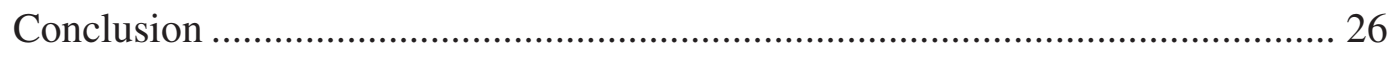

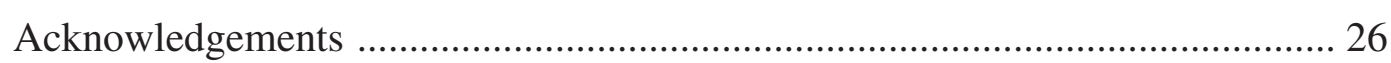

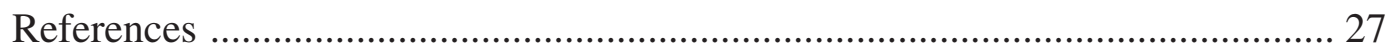

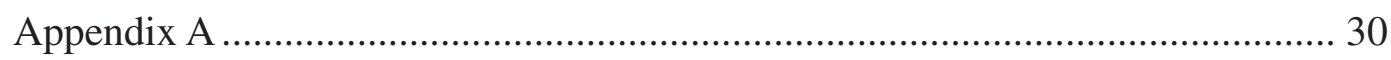

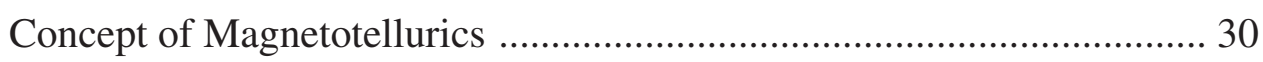

Factors Influencing the Electrical Properties ...................................... 31

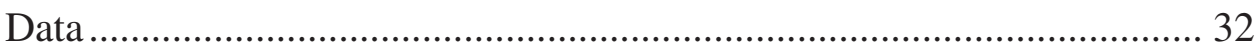




\section{Abstract}

Magnetotelluric data delineate distinct layers and lateral variations above the pre-Tertiary basement. On Pahute Mesa, three resistivity layers associated with the volcanic rocks are defined: a moderately resistive surface layer, an underlying conductive layer, and a deep resistive layer. Considerable geologic information can be derived from the conductive layer which extents from near the water table down to a depth of approximately $2 \mathrm{~km}$. The increase in conductivity is probably related to zeolite zonation observed in the volcanic rock on Pahute Mesa, which is relatively impermeable to groundwater flow unless fractured. Inferred faults within this conductive layer are modeled on several profiles crossing the Thirsty Canyon fault zone. This fault zone extends from Pahute Mesa into Oasis Valley basin. Near Colson Pond where the basement is shallow, the Thirsty Canyon fault zone is several $(\sim 2.5)$ kilometers wide. Due to the indicated vertical offsets associated with the Thirsty Canyon fault zone, the fault zone may act as a barrier to transverse (E-W) groundwater flow by juxtaposing rocks of different permeabilities.

We propose that the Thirsty Canyon fault zone diverts water southward from Pahute Mesa to Oasis Valley. The electrically conductive nature of this fault zone indicates the presence of abundant alteration minerals or a dense network of open and interconnected fractures filled with electrically conductive groundwater. The formation of alteration minerals require the presence of water suggesting that an extensive interconnected fracture system exists or existed at one time. Thus, the fractures within the fault zone may be either a barrier or a conduit for groundwater flow, depending on the degree of alteration and the volume of open pore space.

In Oasis Valley basin, a conductive surface layer, composed of alluvium and possibly altered volcanic rocks, extends to a depth of 300 to $500 \mathrm{~m}$. The underlying volcanic layer, composed mostly of tuffs, fills the basin with about 3-3.5 km of relief on basement. A fault zone, related to the southern margin of the basin, appears to extend up to a depth of about $500 \mathrm{~m}$. The path of groundwater encountering this fault zone is uncertain but may be either to the southwest towards Beatty or to the south towards Crater Flat. 


\section{Introduction}

The Nevada Test Site (NTS) and its surrounding region have been the subject of numerous recent investigations because from the late 1950's until 1992, there were at least 828 underground nuclear tests within the NTS (U.S. Department of Energy, 1994). In the northwestern corner of the NTS, on Pahute Mesa (Figure 1), the groundwater recharges and/or flows through areas where there were 85 underground nuclear tests. At least 77 and probably 80 detonations were sufficiently close to or below the water table subsequently introducing radioactive and chemical contaminants into the groundwater flow system (Laczniak and others, 1996). The NTS is within the Death Valley groundwater flow system (Laczniak and others, 1996). One possible groundwater flow path is from the source of contaminants on Pahute Mesa towards the discharge area at Oasis Valley, north of Beatty, Nevada. The objective of this investigation is to identify and characterize structures that may control groundwater flow from Pahute Mesa to Oasis Valley by the interpretation of magnetotelluric (MT) data.

In October 1997 and March 1998, the U.S. Geological Survey (USGS) collected detailed gravity and MT data over several possible subsurface structures on Pahute Mesa and in Oasis Valley (Mankinen and others, 1998; Schenkel, 1998). The MT data were collected across regional gravity and magnetic features, primarily to provide new insights on associated structures within the top $2 \mathrm{~km}$ of the crust. Of particular interest is a prominent NE-trending linear feature on regional gravity aeromagnetic maps (Mankinen and others, 1999) and on a basin thickness map (Hildenbrand and others, 1999). This feature was originally identified by Grauch and others (1997) and better defined through basin analysis by Hildenbrand and others (1999) who named it the Thirsty Canyon lineament (TCL). Hildenbrand and others (1999) suggest that the source of the TCL is a fault zone, the Thirsty Canyon fault zone (TCFZ), that influenced caldera growth. On Pahute Mesa, the TCFZ coincides with the western margin of the Silent Canyon caldera complex. It extends at least $35 \mathrm{~km} \mathrm{SW}$ into the Oasis Valley basin (Mankinen and others, 1999). The TCFZ and other regional structures (Grauch and others, 1997; Hildenbrand and others, 1999; Mankinen and others, 1999) are studied in more detail by investigating their electrical properties

particularly at the depths of the aquifers. In this region, many of the aquifers are several hundred meters below the water table. Additionally, alteration minerals resulting from groundwater flowing through interconnected fractures in the electrically resistive lava flows and densely welded tuffs can be electrically conductive. Thus, the MT method, capable of delineating rock resistivities several kilometers below the surface, can be a viable tool to map geologic structures possibly influencing groundwater flow.

\section{Geologic Background}

Most of the study area lies on the western margin of the central southwest Nevada volcanic field (SWNVF) caldera cluster (Sawyer and others, 1994), in the southern Great Basin of the western United States. The area lies close to, and may overlap, the Walker Lane-Las Vegas Valley shear zone. The region is underlain, in part, by a thick section of the Cordilleran miogeosynclinal deposits, a complexly deformed and metamorphosed Paleozoic and upper Precambrian sedimentary rock sequence (Ekren, 1968; Noble and others, 1991). Other than some local granitic intrusions, there are no sedimentary or volcanic Mesozoic rocks in the study area (Ekren, 1968; 


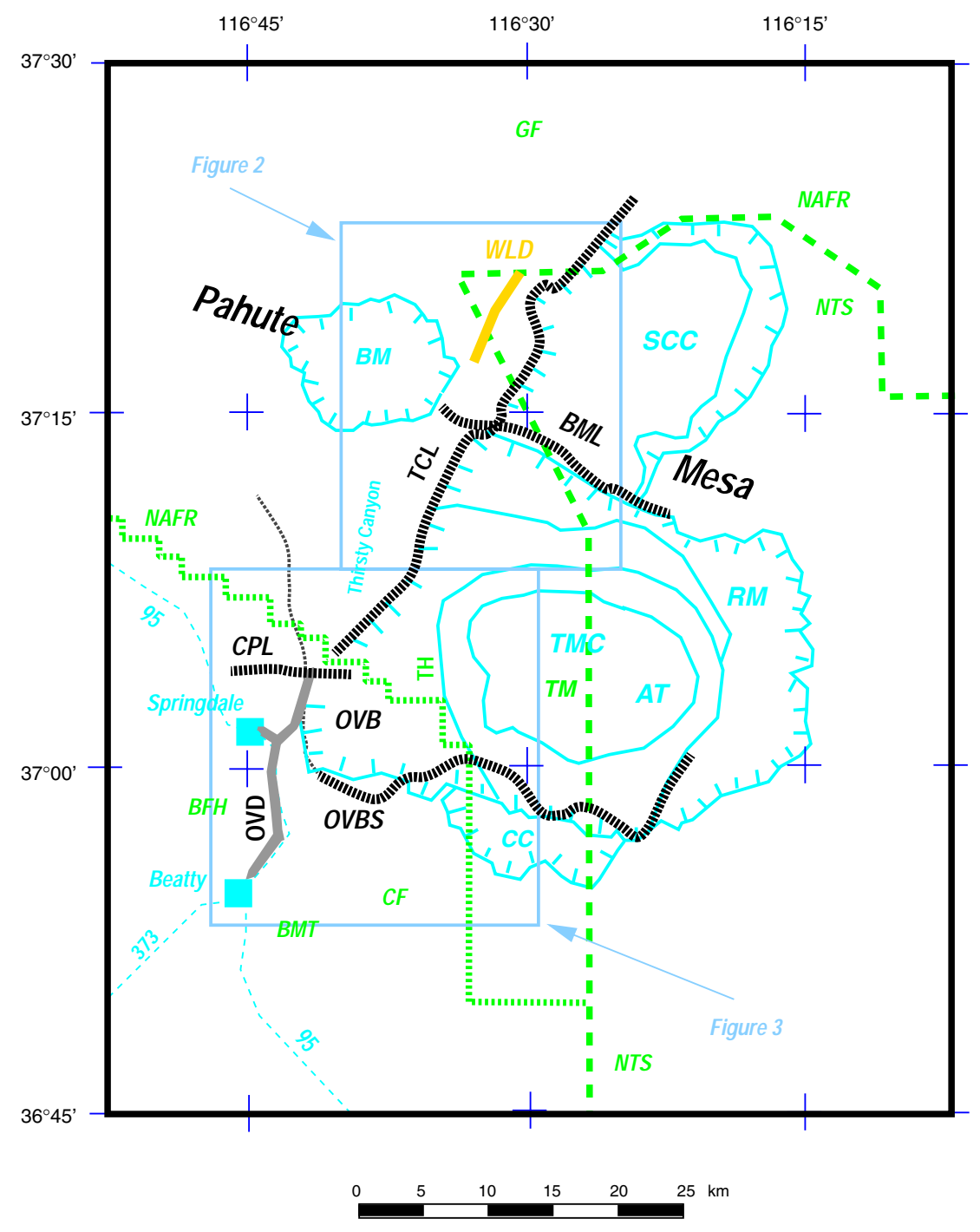

\section{Symbols-Letters}
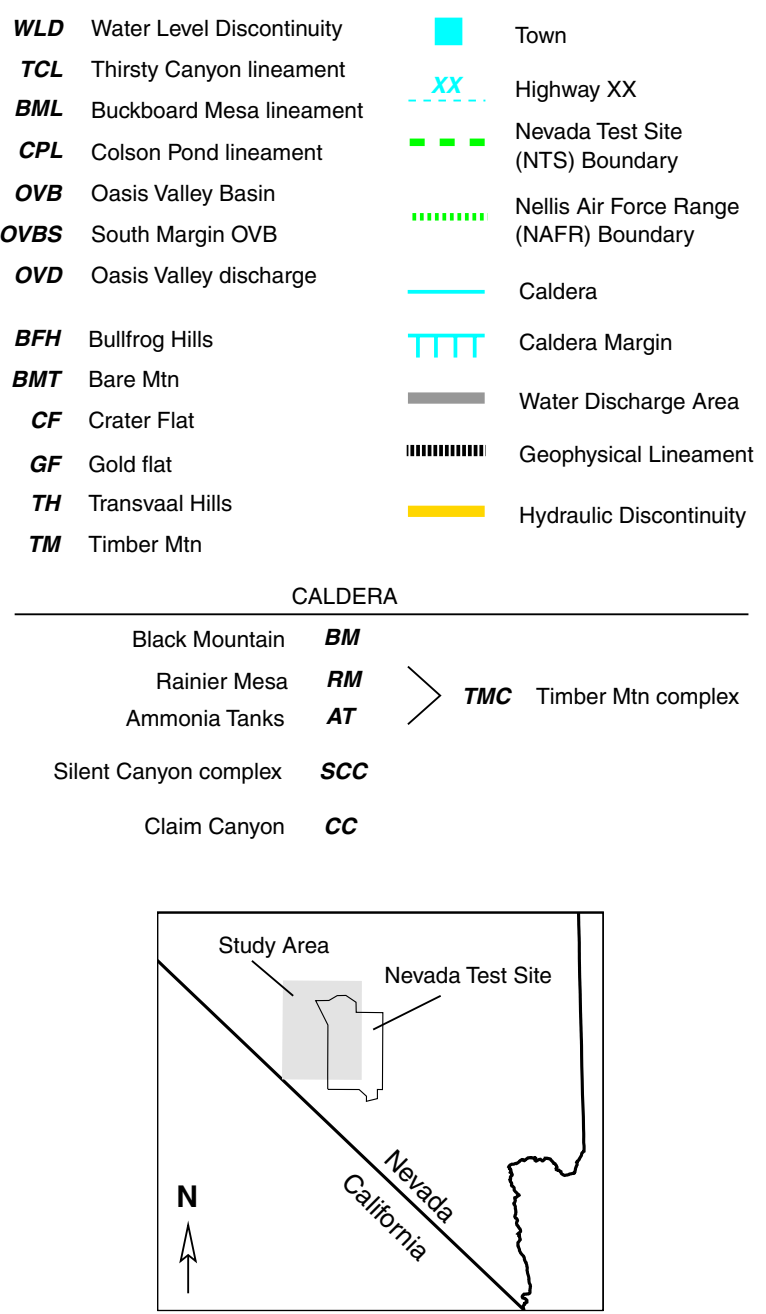

Figure 1: Location map showing the study area in Figures 2 and 3. Boxes show the study areas of the MT surveys. The gray solid lines indicate caldera outlines as defined by Slate (USGS, written communication, 1999). 
Laczniak and others, 1996). The principle volcanic rocks, produced by numerous Tertiary volcanic centers, are ash-flow tuffs and lava flows of rhyolitic and quartz-latitic composition (Ekren, 1968). The Quaternary strata are composed of alluvium filling the basins and low-lying areas and some minor basalt flows.

The SWNVF evolved during the extension related to the formation of the Basin and Range Province in the Tertiary period (Sawyer and others, 1994). Eruptions, which began about 16 million years ago (Ma) and ended about 7.5 Ma, produced several calderas, many which of overlap. Thick complex sequences of the ash-flow tuffs and lava flows fill these calderas, such as the overlapping Silent Canyon caldera complex (SCC), the Claim Canyon caldera (CC), and the Timber Mountain caldera complex (TMC) (Figure 1). The Timber Mountain caldera complex, consisting of the Rainier Mesa caldera (RM) and the younger Ammonia Tanks caldera (AT), overlaps the Silent Canyon caldera complex on the north and Claim Canyon caldera on the south. The Black Mountain caldera (BM) is just outside and northwest of the central SWNVF caldera cluster but the rocks associated with this event blanket a large part of the study area.

The southern part of the study area lies in the Oasis Valley basin, named by Fridrich (USGS, written communication, 1999). This basin is characterized by an absence of exposed bedrock units older than $10 \mathrm{Ma}$ (C.J. Fridrich, USGS, written communication, 1999). This basin is a roughly rectangular, half-graben that formed at the trailing edge of the Fluorspar Hills-Bullfrog Hills detachment fault system (C.J. Fridrich, USGS, written communication, 1999). It lies in a transition zone between the Walker Lane and the Basin and Range regional structural domains (C.J. Fridrich, USGS, written communication, 1999). The west side of Oasis Valley basin is characterized by a large detachment fault system while the east side of the Oasis Valley basin is flanked by Ammonia Tanks caldera.

\section{Magnetotelluric Method}

The MT method is an electromagnetic (EM) sounding technique that uses surface measurements of the natural electric and magnetic fields to infer the subsurface electrical resistivity distribution. The natural source of MT fields originates from lightning discharges and magnetospheric current systems set up by solar activity. MT data collected at various frequencies and locations provide a means to distinguish spatial variations in resistivity since the EM field penetration, which decays exponentially, is related to the frequency and resistivity of the medium. Appendix A discusses the concepts of the MT method and its utility to map structural variations in the subsurface.

From 1965 to 1997 , nearly 200 MT sites have been occupied by other investigators in the vicinity of NTS, primarily in the area of Yucca Mountain. Along with the MT soundings, there have been several controlled source and high frequency EM studies (Hoover and others, 1982a).

Except for the recent studies of Klein (1995) and Lee (Lawrence Berkeley Laboratory (LBL), written communication, 1996) most of these studies used one-dimensional (1D) models to interpret the data. In general, four resistivity layers can suitably model most of these MT data. When low frequencies were measured (Plouff, 1966; Hoover and others, 1982a; Klein 1995) a deep conductive zone is delineated at a depth of 10-50 km. Other studies, including Hoover and others (1982b), Furgerson (1982), and Klein (1995), identify a thin shallow conductor at depths of 1-6 km. Between the deep and shallow conductive layers, a high resistivity $(300-3,000 \Omega \cdot \mathrm{m})$ 
unit exists (Hoover, 1982b; Klein, 1995). In addition to determining vertical changes in resistivity, LBL (KiHa Lee, LBL, written communication, 1996) demonstrated that the continuous profiling technique (described in Appendix A) could locate faults (e.g., Ghost Dance fault) in Yucca Mountain.

\section{Electrical Properties}

The capability of the MT method to define geologic structures hinges on relations of electrical resistivity to the composition of rocks and geologic processes affecting rocks. In general, the resistivities of geologic units are dependent on the temperature, volume fraction, connectivity, and ionic-composition of the fluid in the pore spaces, as well as the conductive mineral content.

The anticipated representative resistivity ranges for rock types found in the study area are given below (Table 1) using the relations found in Appendix A, Factors Influencing Electrical Properties. The selected values are largely based on data from Snyder (1968), Blankennagel and Weir (1973) and on information from electrical logs and lithologic descriptions in Kilroy and Savard (1996).

\begin{tabular}{|c|c|c|}
\hline Rock Type & Geologic Process & Resistivities $(\Omega \cdot \mathbf{m})$ \\
\hline \multirow{2}{*}{ Alluvium } & saturated & $20-70$ \\
\cline { 2 - 3 } & unsaturated & $70-200$ \\
\hline \multirow{2}{*}{$\begin{array}{c}\text { Air-Fall } \\
\text { Tuffs }\end{array}$} & non altered & $\sim 100+$ \\
\cline { 2 - 3 } Ash-Flow & altered & $5-<100$ \\
Tuffs & non/slightly welded & $\sim 100$ \\
\cline { 2 - 3 } & moderately welded & $100-200$ \\
\cline { 2 - 3 } & densely welded & $200-1,000+$ \\
\cline { 2 - 3 } & altered & $5-<100$ \\
\hline Rhylolite & non altered & $<00-1,000+$ \\
\cline { 2 - 3 } Lavas & altered & $800-10,000$ \\
\hline Basement & & \\
\hline \multirow{2}{*}{$\begin{array}{c}\text { (Carbonates/Clastics/Gran } \\
\text { ite) }\end{array}$} & & \\
\hline
\end{tabular}

Table 1: Representative resistivity values for various rock types and geologic process of the study area.

\section{Magnetotelluric Data}

In October 1997 (Figure 2) and March 1998 (Figure 3), 95 MT sites were occupied on Pahute Mesa and in Oasis Valley along profiles crossing several subsurface structures that may control groundwater flow (Schenkel, 1998). In October 1997, 35 continuous profiling stations and 22 

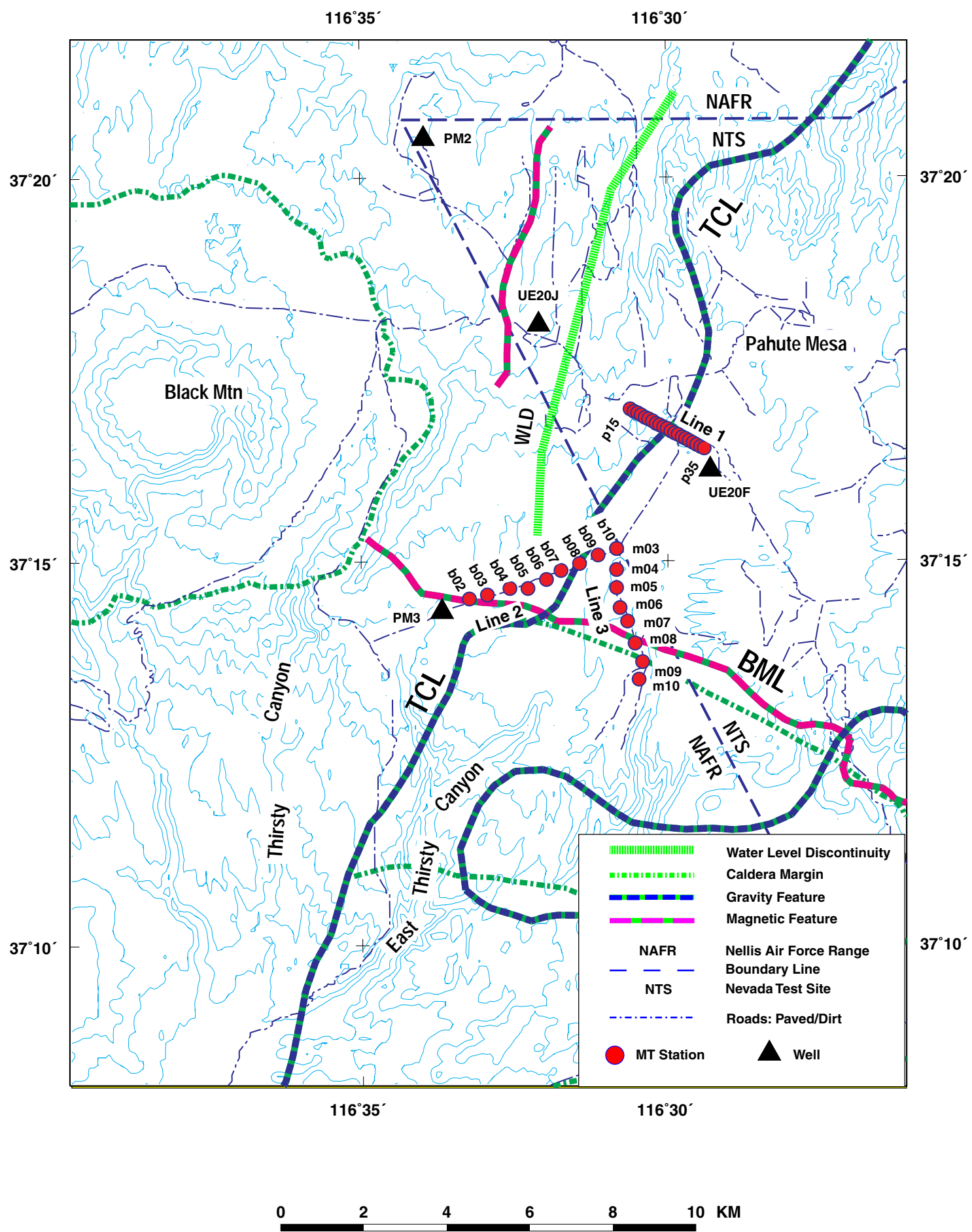

Figure 2: Map of the MT sites in the Pahute Mesa region. Line 1 is a continuous profile with stations p15-p35. Dual-sounding profiles are Line 2 (stations b02-b10) and Line 3 (stations m03-m10). Elevation contours shown as a thin solid line with $50 \mathrm{~m}$ contour interval. Wells are labeled PM2, PM3, UE20F, and UE20J. The Thirsty Canyon lineament (TCL) and Buckboard Mesa lineament (BML) are described by Grauch and others (1997), Hildenbrand and others (1999), and Mankinen and others (1999). The thick gray line (WLD) is the water level discontinuity (Laczniak and others, 1996). 

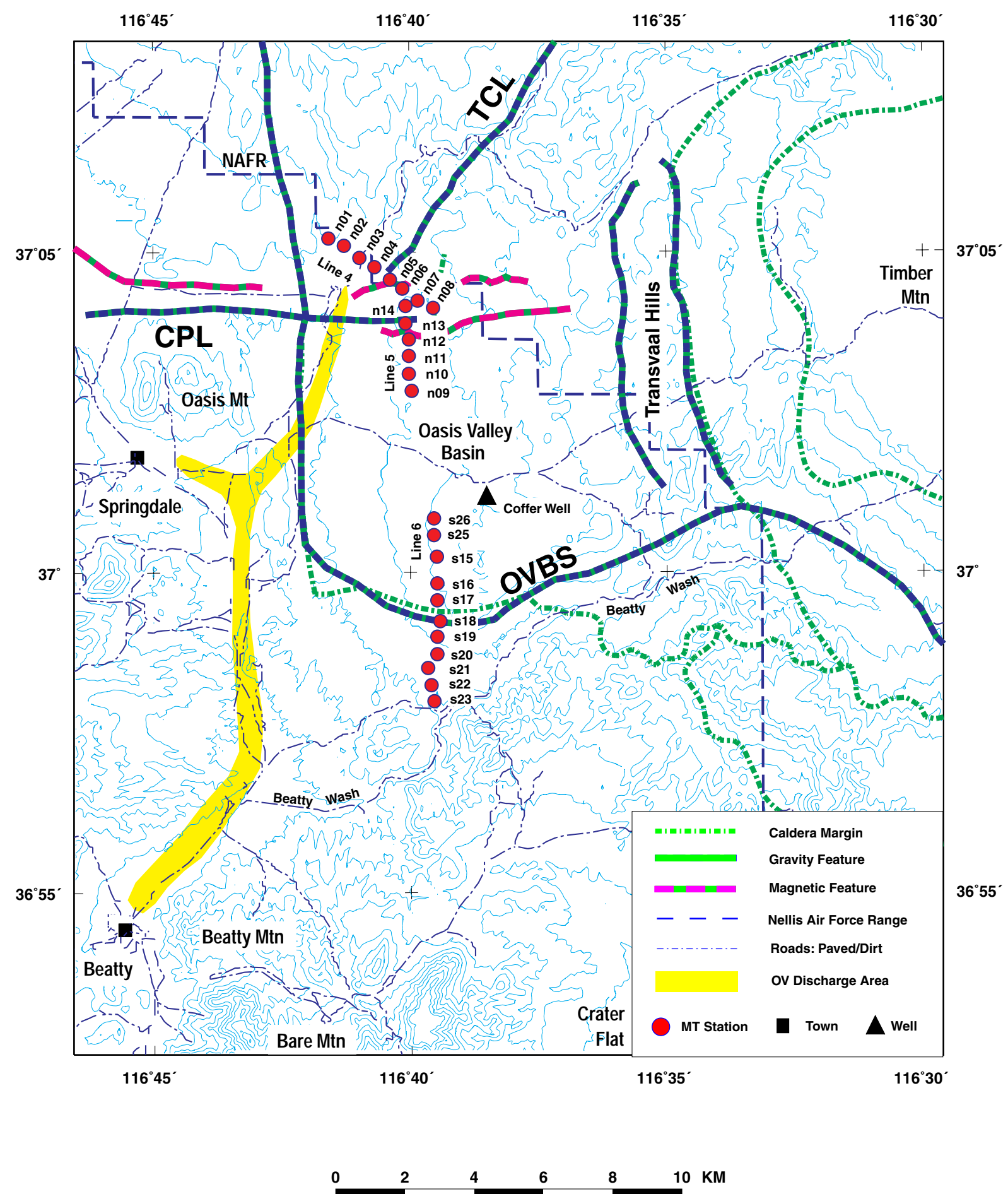

Figure 3: Map of the MT sites in the Oasis Valley region. Dual-sounding MT profiles are Line 4 (stations n01-n08) near the terminous of the Thirsty Canyon lineament (TCL), Line 5 (stations n06, n09-n14) crossing the Colson Pond lineament (CPL), and Line 6 (sites s15-s26) crossing the southern margin of the Oasis Valley basin (OVBS). These features are described by Grauch and others (1997), Hildenbrand and others (1999), and Mankinen and others (1999). Elevation contours shown as a thin solid line with $50 \mathrm{~m}$ contour interval. The gray area represents the Oasis Valley groundwater discharge area. 
individual soundings were acquired, while 38 individual soundings were gathered in March 1998. The sounding sites were collected in pairs (500 $\mathrm{m}$ separation) so as to employ remote referencing for noise reduction (Gamble and others, 1979; Furgerson, 1982). Continuous profiling, which combines several contiguous $E x$-fields for each setup of $E y, H x$, and $H y$ along a profile (Torres-Verdin, 1991; Torres-Verdin and Bostick, 1992), used a fixed remote reference and spanned $700 \mathrm{~m}$. The electrode spacing used in October 1997 was $100 \mathrm{~m}$, while in March 1988 it was $50 \mathrm{~m}$. Orthogonal components of the electric $(\mathrm{E})$ and magnetic $(\mathrm{H})$ fields were collected in the frequency band of 0.01 to $175 \mathrm{~Hz}$.

Three profiles ( 1 continuous and 2 sounding) were sited to cross the TCL as defined by Hildenbrand and others (1999). The source of the TCL is the TCFZ (Hildenbrand and others, 1999). Because the inferred width of this fault zone is large $(\sim 2 \mathrm{~km})$ (Mankinen and others, 1999), the TCL drawn as a line on maps (Figures 2 and 3) is ambiguous with respect to its exact location over the broad fault zone. The northernmost MT profile (Line 1, Figure 2) crosses the TCL near the western margin of the Silent Canyon caldera complex (SCC, Figure 1). The middle profile (Line 2, Figure 2) obliquely crosses the TCL near well PM3. The southernmost profile (Line 4, Figure 3) is in Oasis Valley basin where the TCL may terminate.

The remaining profiles include a NS sounding profile (Line 3, Figure 2) that crosses the ESEstriking magnetic lineament, named the Buckboard Mesa lineament (BML) (Mankinen and others, 1999), which may coincide with the topographic wall of the Rainier Mesa caldera. Two NS sounding profiles in Oasis Valley basin (Lines 5 and 6, Figure 3) cross the Colson Pond Lineament (CPL) and the east-striking accommodation zone, called the Hot Springs lineament (HSL), respectively (C.J. Fridrich, USGS, written communication, 1999). However, from geophysical data (Mankenin and others, 1999), the HSL of Fridrich (USGS, written communication, 1999) may actually be two separate structures (Figure 3). The easternmost structure bounds the southern end of Oasis Valley basin (OVBS, Figure 3) which appears to coincide with the southern structural margin of the Rainier Mesa caldera.

\section{MT Methodology}

The MT data analysis program (MTWORKS) developed by Mike Hoversten of LBL provides numerous data processing and interpretative capabilities used in deriving geologic models. The forward modeling and inversion algorithms used for this study assume a two-dimensional (2D) cross section divided into cells with uniform resistivity. For regions along the profile and near the earth's surface, the height and width of the cells used in the inversion were about 50-75 m and 50-100 m, respectively. Away from the surface and outside the area of interest, the cells increased in size based on the frequency (wavelength) of the data. The inversion codes perform a nonlinear least-squares regression on the data to calculate the resistivity of each cell. The iterative process minimizes the objective function, composed of the squared misfit and a smoothest operator. Iteration continues until the objective function reaches some tolerance value based on the noise level of the data.

The inversion process requires an initial guess for the resistivity model. Based on the MT data, four-layer and three-layer models were selected from as our initial guess for the profiles on Pahute Mesa and Oasis Valley basin, respectively. The resolution of resulting modeled structures 
decreases with depth and lateral position away from the center of the profile. Without a priori information, the maximum depth of investigation at the center of the profile is approximately equal to the length of the profile. However, with additional knowledge of other geophysical information, such as modeled gravity structures, one can make a reasonable estimate of the resistivity structure beneath much of the profile. Of the MT profiles, only Line 1 was nearby a well (UE20F) with abundant geological and geophysical data and sufficiently deep. This information provided additional constraints and thus presumably a better starting model.

For each profile, cross-sections of the calculated resistivity model with interpretative structures are provided (Figures 4-9). Appendix A has plots of the model-fit to the field data for the apparent resistivity and impedance phase. The upper $5-7 \mathrm{~km}$ is shown in these cross sections. However, at locations where the basement is shallow (e.g., Oasis Valley basin) only the upper 2-3 km is shown. In the cross-sections, the solid white line represents the pre-Tertiary (pT) boundary as estimated by Hildenbrand and others (1999). Solid black lines show interpreted resistivity boundaries. White dashed line indicates the depth of the water table. For the profiles in Oasis Valley basin (Figures 7-9), no water table line is shown since the water table is essentially at the surface. Black long-dashed lines show inferred or interpreted faults, while black short-dashed lines represent faults that are more speculative. We estimate that the inferred structures are properly located laterally to within about $500 \mathrm{~m}$ and the error in their dips can be roughly as high as $20^{\circ}$.

\section{Pahute Mesa MT Profiles}

In Pahute Mesa, the volcanic sections are composed of a complex sequence of lavas and tuffs characterized by varying degrees and types of alteration, as well as widely varying electrical properties. Figure 4 shows the electric log and the lithologic and alteration sections from well UE20F (Warren and others, 1999). Table 2 summarizes the relationship between alteration, lithology, and average electrical resistivity for this well. The changes of the electrical resistivity correlates with the variations in alteration and lithology. In this well, the lavas and flow breccias are generally resistive while the resistivities of the welded tuffs greatly vary depending on the type and degree of alteration. In general, zeolitic rocks tend to have lower resistivities and rocks identified as vitric or devitrified are resistive.

Using MT to identify individual geological units in the Southwestern Nevada volcanic field is very difficult and probably impossible. The MT data from Line 1 on Pahute Mesa is a good example of how heterogeneous units are generalized into few uniform units in the inversion and modeling process. Regardless of the complex bedding of the volcanic rocks with varying electrical properties seen in the nearby well UE20F, the MT data show only four distinct layers (three in the upper $5 \mathrm{~km}$ ) that can be identified. This lack of resolution is due to the inherent smoothness of the data (see Appendix) of the MT method. The thinner resistivity units can be averaged to form a larger unit with an equivalent electrical conductance (single electrical resistivity). Thus, this method is poorly suited for identifying individual geologic units but is well suited for delineating gross structures caused by resistivity variations, such as fault zones with significant vertical offsets.

The four distinct electrical units can be identified from the apparent resistivity sounding curves of the data collected on Pahute Mesa (Figures 5-7). A relatively thin resistive surface layer, a 
conductive unit, a thick sequence of resistive material, and a deep $(\geq 15 \mathrm{~km})$ conductive basal zone. Hildenbrand and others (1999) calculated the depth to the pT surface from the inversion of gravity data. This surface was used as a constraint in the models. In this region, the pT rock is composed probably of carbonate and clastic sedimentary rock that can be intruded locally by younger granite. From the electric well-log that penetrated the pT boundary, these rocks are highly resistive (Maldonado and others, 1979). Using the pT surface as a resistivity boundary, the resistive third unit was divided into two zones, the upper section representing dense Tertiary volcanic rock (Hildenbrand and others, 1999; Mankinen and others, 1999) and the lower part expressing pT basement.

Figure 5 is the resistivity model obtained from the inversion of the MT data from profile Line 1. Well UE20F is located about 150-200 m southeast of Line 1 (see Figure 2). The resistivity log and the lithology and alteration data (Warren and others, 1999) from well UE20F (Figure 4) were used for the initial guess for the resistivity model. Average resistivities were calculated from the electric log at intervals where the lithology and alteration changed. These average resistivities were used for the resistivity cells east of station p35. These model cells were fixed during the inversion process. Initial resistivities of the cells within and west of the profile were based on a four layer model and the gravity models of Hildenbrand and others (1999) and Mankinen and others (1999). The cells west of station p15 were allowed to vary slightly from the initial guess. The model cells within the profile were allowed to freely change during the inversion process.

In Figure 5, the resistivity cross-section for the continuous profile data (sites p15-p35) shows a resistive surface layer, generally $100-250 \Omega \cdot \mathrm{m}$, with localized surface (electrical) inhomogeneities. The second layer is conductive $(\sim 30-60 \Omega \cdot \mathrm{m})$ which extends from above the water table down to a depth of approximately $2 \mathrm{~km}$. This unit appears more conductive to the west of station p23 where a number of near vertical changes in resistivity suggests a zone of complex faulting. The inferred fault zone appears to correlate with the TCFZ and the fractures are probably associated with the Silent Canyon caldera complex. The bottom of the conductive second layer is down-dropped to the east of the inferred fault zone (possibly up to $500 \mathrm{~m}$ ). Additionally, the base of this layer slopes upward towards the east but is about $200 \mathrm{~m}$ deeper than that predicted from the electric log of well UE20F. The third resistive layer $(300-500 \Omega \cdot \mathrm{m})$ may also be downdropped to the east by this fault zone. The model shows that the thickness of this layer decreases from east $(\sim 1800 \mathrm{~m})$ to west $(\sim 800 \mathrm{~m})$. Between 3.2-3.8 km, a conductive zone appears which did not changed from the initial guess model. Eliminating this deep somewhat conductive zone did not effect the overlying results. These relatively small changes in resistivity over a limited depth extent do not affect the final model since these changes occur at great depths. The deepening of basement and the thickening of the overlying volcanic layers along the eastern part of the profile may reflect the basin associated with Silent Canyon caldera.

The resistivity cross-section of Line 2 (stations b02-b10) is shown in Figure 6. Since the stations were collected obliquely to the TCL, the data were rotated orthogonal to the TCL. The modeled resistivities in the surface layer (approximately 200-600 m thick) are highly variable (40-800 $\Omega \cdot \mathrm{m})$. Similar to Line 1 , the model suggests that the inferred TCFZ is more conductive and faulted. To the east of these inferred faults, the conductive $(10-50 \Omega \cdot \mathrm{m})$ second layer may dip to the east into the Silent Canyon caldera. In the model, the conductive second layer is more resistive $(50-80 \Omega \cdot \mathrm{m})$ west of the interpreted western boundary of the TCFZ. The underlying resistive 


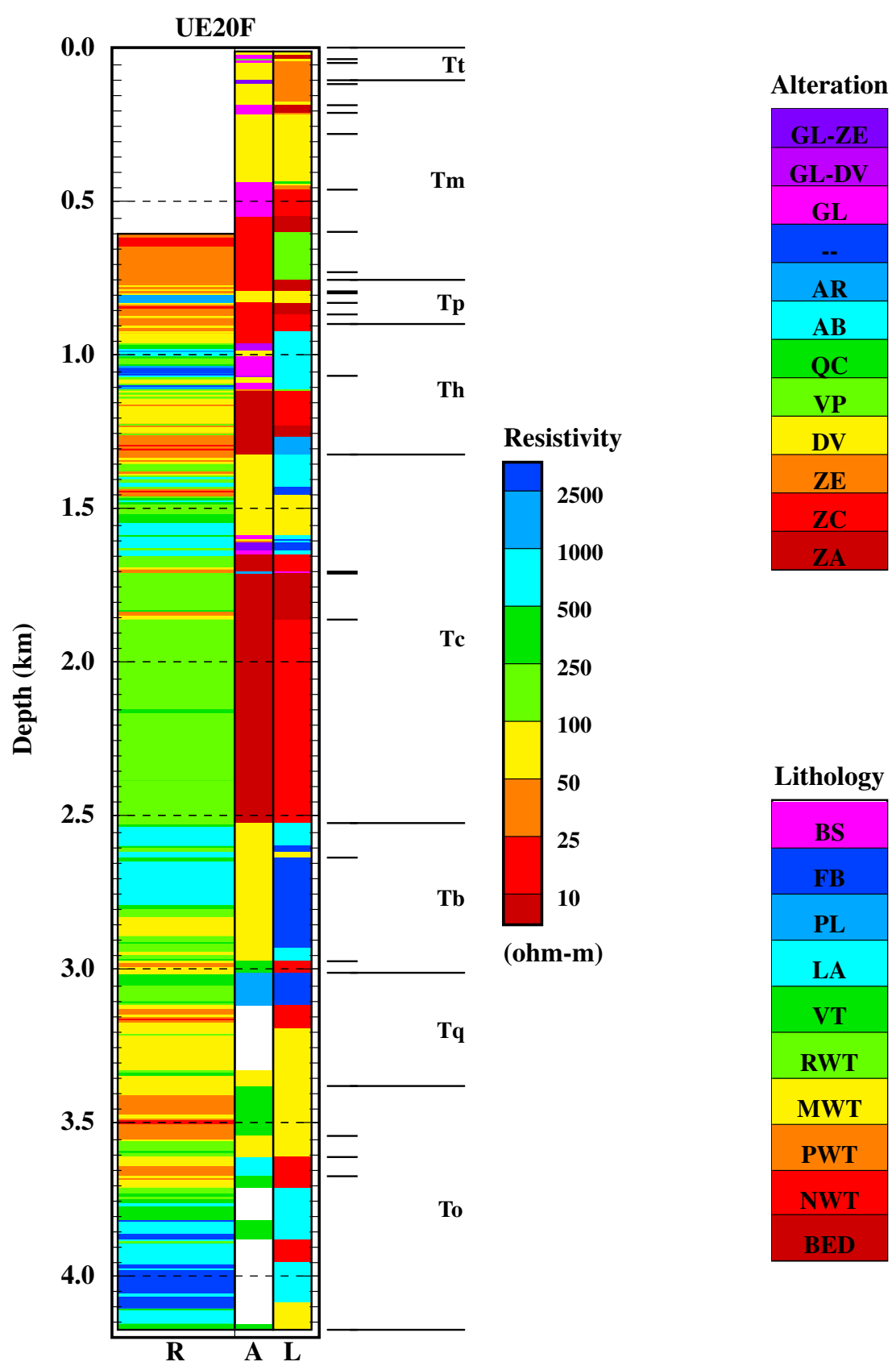

Figure 4: Resistivity log (R), lithology (L), and alteration (A) cross-section (Warren and others, 1999) for well UE20F. Lithology symbols are LA (lava), FB (flow breccia), BS (basalt), PL (pumiceous lava), BED (bedded tuffs), NWT (non-welded tuffs), MWT (moderately welded tuffs), and RWT (reworked tuffs). Alteration symbols are GL (vitric), GL-ZE (vitric and minor zeolites), GL-DV (vitric and minor devitrified), DV (devitrified), AR (argillic), AB (albitic), QC (silicic with chalcedony), ZE (zeolitic), ZC (zeolitic with clinophlolite), ZA (zeolitic with analcime). Stratigraphic symbols are Tt (Thirsty Canyon Group), Tm (Timber Mountain Group), Tp (Paintbrush Group), Th (Calico Hills Formation), Tc (Crater Flat Group), Tb (Belted Range Group), Tq (Volcanics of Quartz Mountain), and To (Volcanics of Oak Spring Butte). 


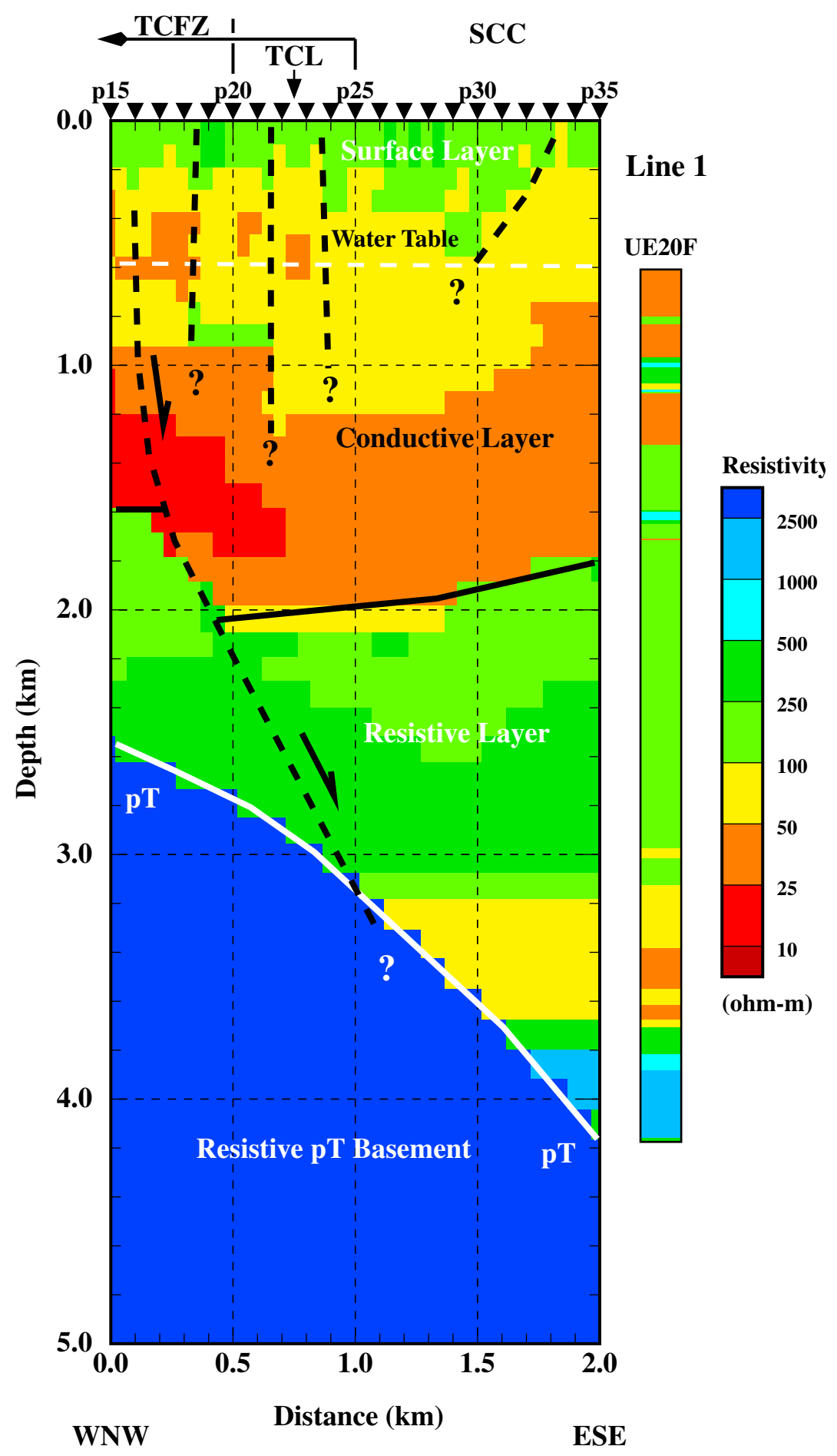

Figure 5: Resistivity cross-section based on the 2D inversion of the continuous profile MT data along Line 1. The profile direction was 125 degrees from true north. The data were collected across the northern end of the Thirsty Canyon gravity lineament. Inferred location of the Silent Canyon caldera (SCC), Thirsty Canyon lineament (TCL) and Thirsty Canyon fault zone (TCFZ) are shown. The black solid lines represent inferred resistivity layer boundaries. The black long dashed lines are inferred faults. The black short dashed lines are more speculative faults. The while solid and dashed lines are the basement surface and water table, respectively. 


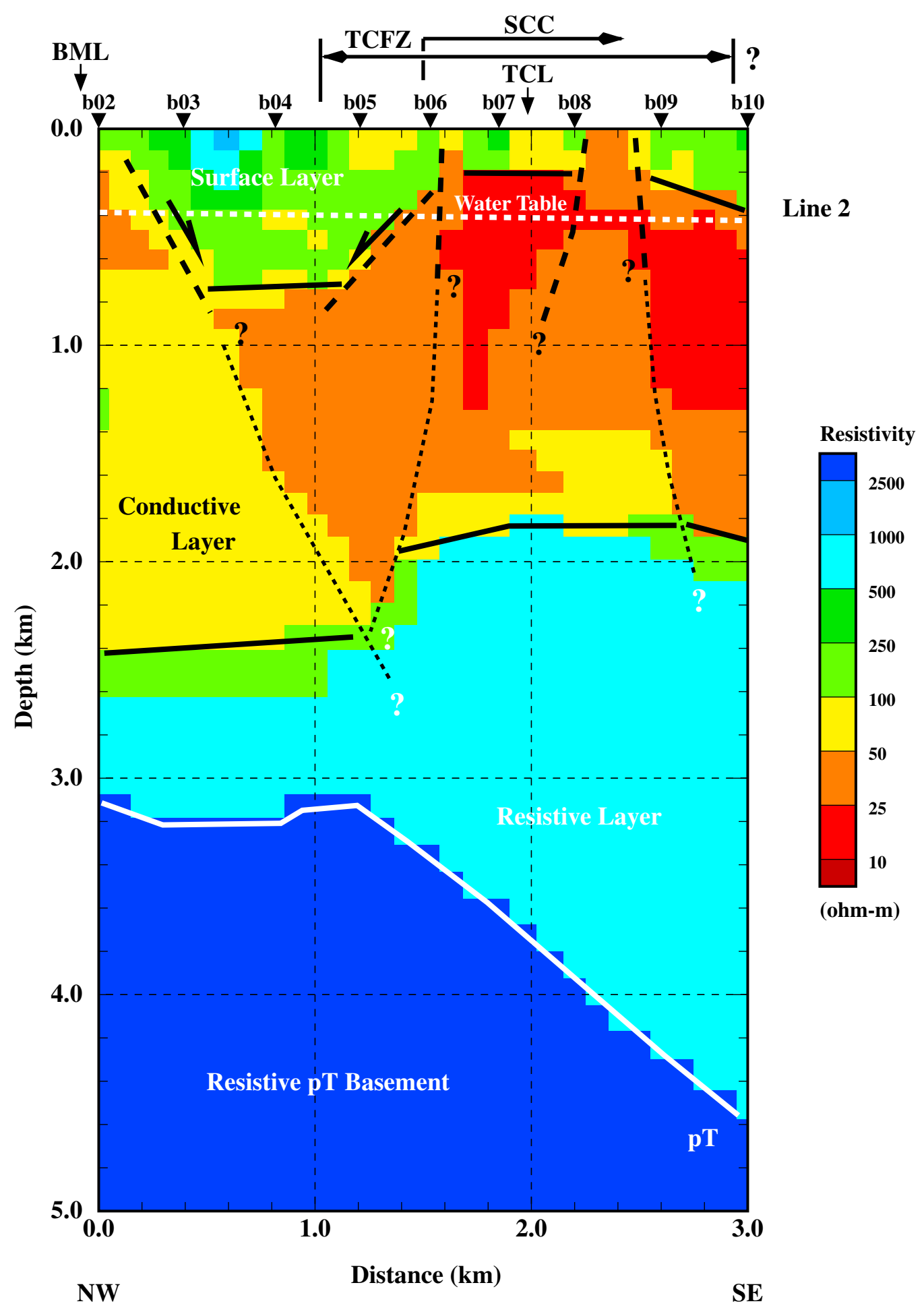

Figure 6: Resistivity cross-section based on the 2D inversion of the MT sounding data along Line 2. Inferred locations of structures are Buckboard Mesa lineament (BML), Silent Canyon caldera (SCC), Thirsty Canyon lineament (TCL), and Thirsty Canyon fault zone (TCFZ). The black solid lines represent inferred resistivity layer boundaries. The black long dashed lines are inferred faults. The black short dashed lines are more speculative faults. The while solid and dashed lines are the basement surface and water table, respectively. 


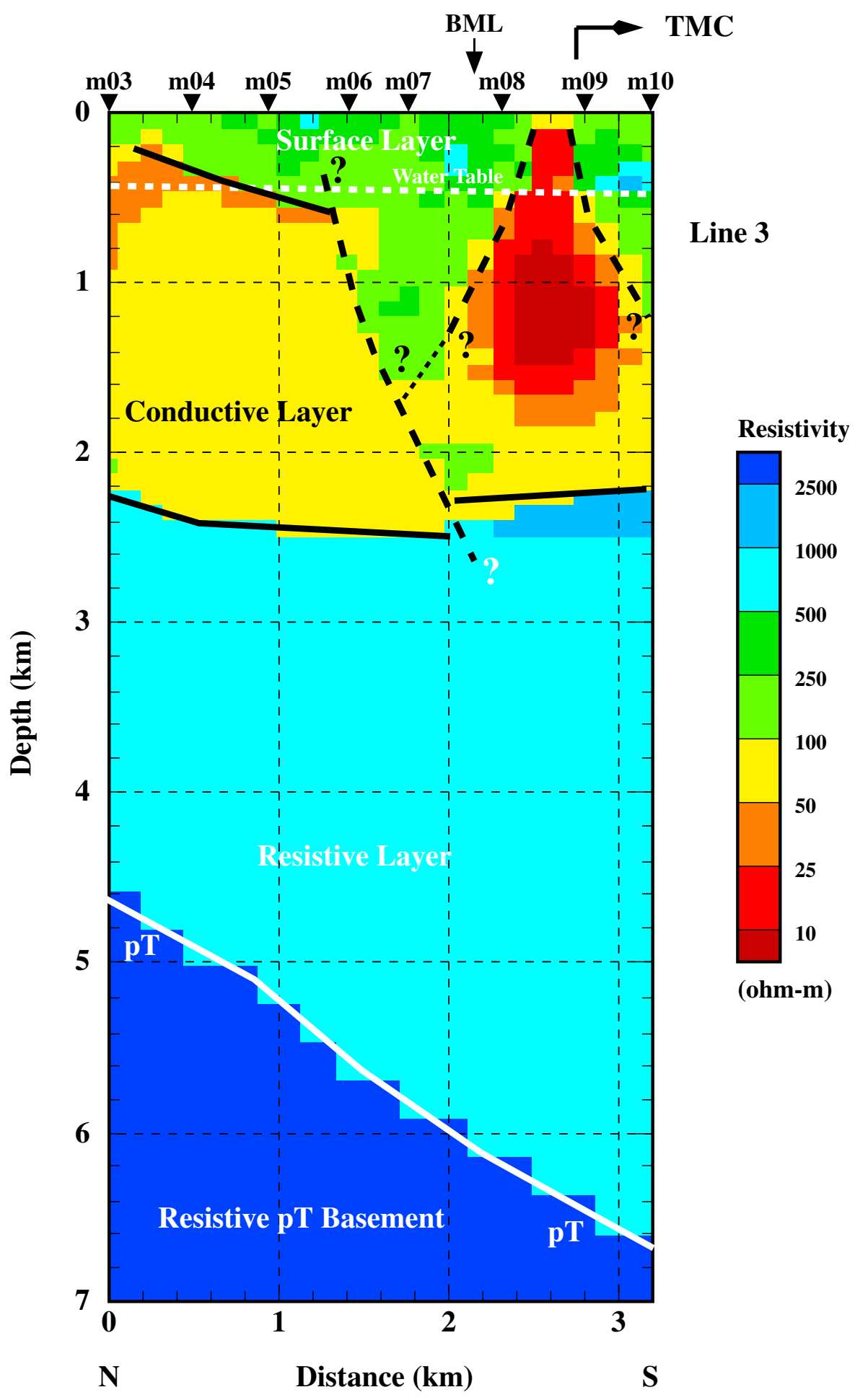

Figure 7: Resistivity cross-section based on the 2D inversion of the MT sounding data along Line 3. The data were collected across the Buckboard Mesa magnetic lineament (BML) and the Timber Mountain caldera (TMC). ). The black solid lines represent inferred resistivity layer boundaries. The black long dashed lines are inferred faults. The black short dashed lines are more speculative faults. The while solid and dashed lines are the basement surface and water table, respectively. 


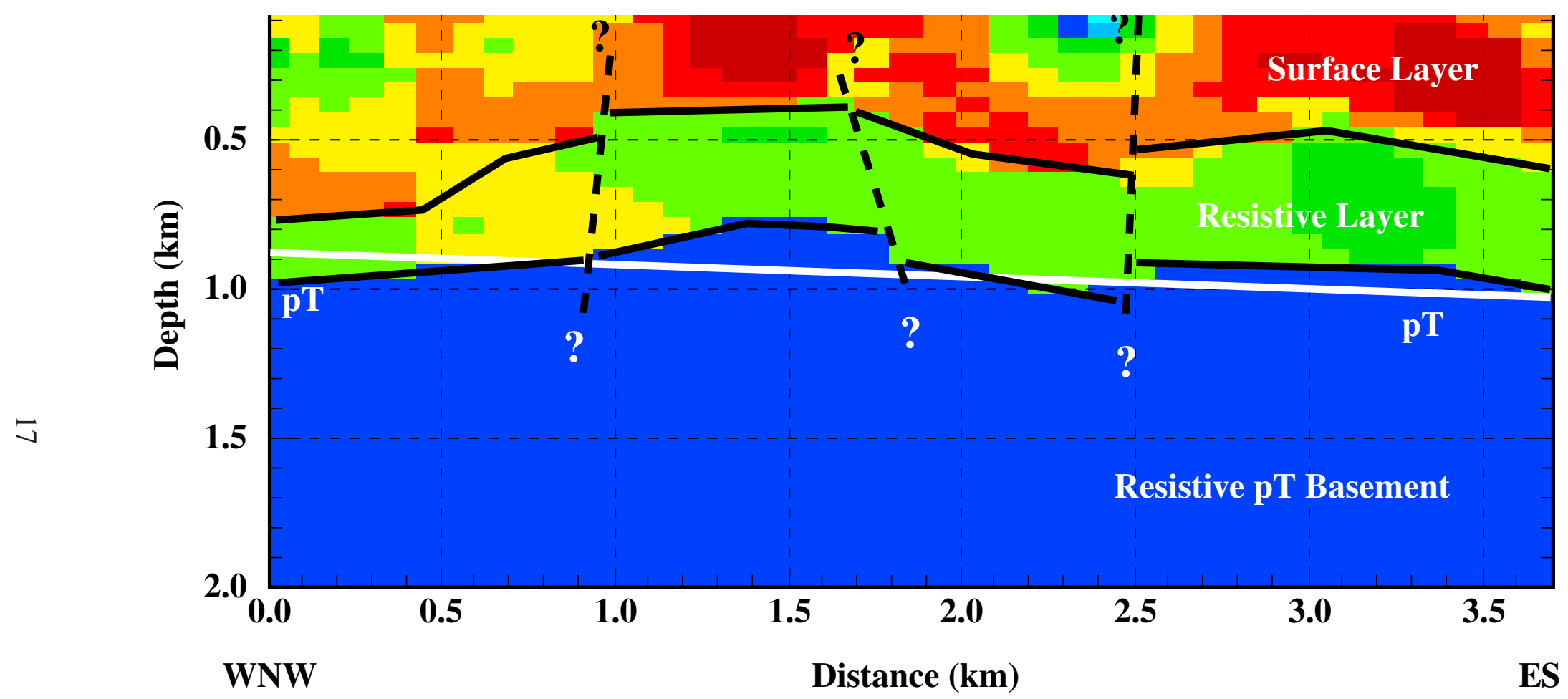

Figure 8: Resistivity cross-section based on the 2D inversion of the MT sounding data along Line 4. The data were collected across southern end of the Thirsty Canyon lineament (TCL) and the associated fault zone (TCFZ) near and on the Nellis Air Force Range. The black solid lines represent inferred resistivity layer boundaries. The black long dashed lines are inferred faults. The black short dashed lines are more speculative faults. The while solid line is the basement surface. 


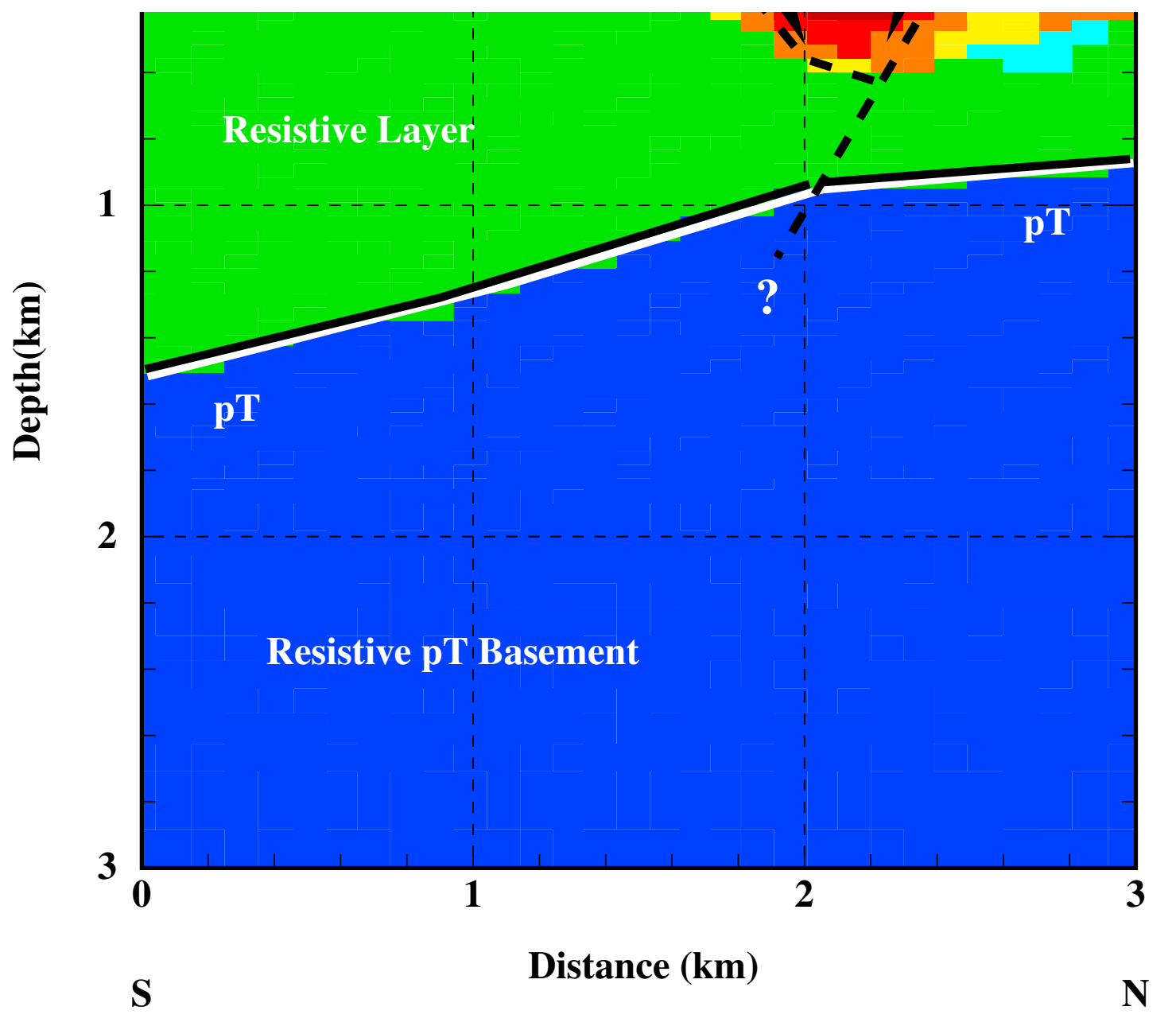

Figure 9: Resistivity cross-section based on the 2D inversion of the MT sounding data along Line 5. The data were collected across east-west trending Colson Pond lineament (CPL) and magnetic lineament (Mag). The black solid lines represent inferred resistivity layer boundaries. The black long dashed lines are inferred faults. The black short dashed lines are more speculative faults. The while solid line is the basement surface.

layer $(>500 \Omega \cdot \mathrm{m})$ appears to be thicker $(\sim 2 \mathrm{~km})$ within the Silent Canyon caldera but thins $(\sim 500$ $\mathrm{m})$ outside the caldera. The pT basement dips from west to east into the Silent Canyon caldera.

Line 3 (stations m03-m10) crosses the Buckboard Mesa lineament (BML, Figure 7). The model shows that the resistive surface layer thickens between $\mathrm{m} 06$ and m08. An inferred south-dipping fault beneath station m06 divides the conductive second layer (50-100 $\Omega \cdot \mathrm{m})$ into a thick $(\sim 2 \mathrm{~km})$ zone on the north and a thinner $(\sim 800 \mathrm{~m})$ zone on the south. Between station m08 and m09 a highly conductive zone extends from near the surface down into, and possibly through, the conductive second horizon. The underlying resistive third layer $(\sim 700 \Omega \cdot \mathrm{m})$ thickens from $2 \mathrm{~km}$ to $4 \mathrm{~km}$ as the pT basement surface dips which possibly reflects the thickening of volcanic rocks southward within the Timber Mountain caldera. 


\begin{tabular}{c|c|c|c} 
Lithology & Alteration & $\begin{array}{c}\text { Average } \\
\text { Resistivity } \\
(\boldsymbol{\Omega} \cdot \mathbf{m})\end{array}$ & $\begin{array}{c}\text { Total Thickness } \\
(\mathbf{m})\end{array}$ \\
\hline LA & -- & 2581 & 305 \\
\hline LA & GL & 1670 & 101 \\
\hline LA & GL-DV & 403 & 27 \\
\hline LA & DV & 391 & 266 \\
\hline LA & QC & 2318 & 66 \\
\hline LA & ZE & 919 & 9 \\
\hline LA & ZC & 60 & 37 \\
\hline FB & GL-ZE & 757 & 21 \\
\hline FB & DV & 471 & 338 \\
\hline FB & AR & 223 & 107 \\
\hline BS & AR & 41 & 5 \\
\hline PL & ZA & 38 & 56 \\
\hline BED & ZA & 140 & 191 \\
\hline BED & ZC & 61 & 74 \\
\hline NWT & -- & 398 & 144 \\
\hline NWT & AB & 51 & 61 \\
\hline NWT & QC & 63 & 73 \\
\hline NWT & ZA & 161 & 833 \\
\hline NWT & ZC & 48 & 66 \\
\hline MWT & & 693 & 210 \\
\hline MWT & DV & 390 & 312 \\
\hline MWT & QC & 70 & 180 \\
\hline RWT & ZC & 28 & 159 \\
\hline RWT & ZE & 430 & 10
\end{tabular}

Lithology Symbols: $\mathrm{LA}=$ lava, $\mathrm{FB}=$ flow breccia, $\mathrm{BS}=$ basalt, $\mathrm{PL}=$ pumiceous lava, $\mathrm{BED}=$ bedded tuffs, $\mathrm{NWT}=$ non-welded tuffs, $\mathrm{MWT}=$ moderately welded tuffs, $\mathrm{RWT}=$ reworked tuffs.

Alteration Symbols: GL $=$ vitric, GL-ZE $=$ vitric and minor zeolitic, GL-DV $=$ vitric and minor devitric, $\mathrm{DV}=$ devitrified, $\mathrm{AR}=$ argillic, $\mathrm{AB}=$ albitic, $\mathrm{QC}=$ silicic with chalcedony, $\mathrm{ZE}=$ zeolitic, $\mathrm{ZC}=$ zeolitic with clinophlolite, $\mathrm{ZA}=$ zeolitic with analcime. Table 2: Table of alteration, lithology and average electrical resistivity for well UE20F.

\section{Oasis Valley Basin MT Profiles}

The MT soundings collected in Oasis Valley basin (Figures 8-10) detect only two resistivity layers above the pT basement. A conductive surface layer is produced, in part, by the conductive groundwater (typically $<5 \Omega \cdot \mathrm{m}$ ) and the very shallow water table. For Figures $8-10$, the water table line is not shown since the water level is at or very near the surface. The dissolved solids concentration and conductivity measured from water samples in wells at the mouth of Thirsty Canyon are $\sim 440 \mathrm{mg} / \mathrm{l}$ and $\sim 650 \mu \mathrm{S} / \mathrm{cm}(\sim 1.5 \Omega \cdot \mathrm{m})$, respectively (White, 1979; Thomas, written samples in wells at the mouth of Thirsty Canyon are 440 $\mathrm{mg} / \mathrm{l}$ and $\sim 650 \mu \mathrm{S} / \mathrm{cm}(\sim 1.5 \Omega \cdot \mathrm{m})$, respectively (White, 1979; Thomas, written 
communication, 1998). A stratigraphic cross-section from the Coffer well (Figure 3; Grauch and others, 1997) shows at least $200 \mathrm{~m}$ of alluvium or valley fill. Because the conductive layer in the models is usually thicker than $200 \mathrm{~m}$, this layer probably includes altered tuffs. An intermediate resistive layer, probably volcanic rocks, lies between the conductive surface and resistive the pT basement.

The WNW-trending Line 4 (sites n01-n08) in Figure 7, near the possible termination of the TCFZ (Mankinen and others, 1999) shows that basement shallows ( 1km). Similar to Lines 1 and 2, the TCFZ appears to be characterized by higher conductivities and vertical discontinuities. Between sites n05 and n06, the model shows a surface resistive zone that may be associated with a magnetic low (Mankinen and others, 1999). The moderately resistive second layer (100-500 $\Omega \cdot \mathrm{m}$ ) undulates (probably due to faulting) and has a thickness of $\sim 400 \mathrm{~m}$ (east of station n03).

The north-south profile (Line 5, Figure 8) crosses the Colson Pond lineament (CPL). The model shows that the surface conductive layer $(<10-50 \Omega \cdot \mathrm{m})$ is about 300-400 $\mathrm{m}$ thick. Between station $\mathrm{n} 12$ and $\mathrm{n} 14$, this layer thickens $(\sim 700 \mathrm{~m})$ possibly due to alteration within a fault zone. This interpreted fault zone may extend from the surface conductive layer down into the basement. The unaltered volcanic layer (middle layer) is about $500 \mathrm{~m}$ thick to the north and thickens southward to $\sim 1.2 \mathrm{~km}$ on the southern end of the profile. The resistive $(\geq 3,000 \Omega \cdot \mathrm{m}) \mathrm{pT}$ basement dips southward beginning in the region of the interpretative fault zone.

The north-south profile (Line 6, Figure 9) crossing the southern margin of Oasis Valley basin (OVBS, Figure 3) shows a shallow pT basement on the south end of the profile, which rapidly descends northward into the Oasis Valley basin. The variable thickness of the conductive (10-50 $\Omega \cdot \mathrm{m})$ surface layer is probably related to degrees of alteration. However, below station s18, the model shows a very conductive block extending into the resistive $(300-800 \Omega \cdot m)$ second unit. Below the conductive surface layer, the resistive zone may be composed of two electrically different units. The overlying resistive $(\sim 800 \Omega \cdot \mathrm{m})$ layer extends to a depth of about $2 \mathrm{~km}$ and appears to terminate to the south beneath stations s22 and s23. The thickest section of this unit, below site s16 and s15, corresponds with a local magnetic low (Mankinen and others, 1999). This relatively thick upper resistive layer may possibly to due to a dense lava flow. The underlying less resistive $(\sim 300 \Omega \cdot \mathrm{m})$ layer fills the basin north of the inferred fault zone and may be composed of volcanic tuffs. An alternative model that fits the MT data is a resistive dome (700$1,000 \Omega \cdot \mathrm{m}$ ), possibly a rhyolitic dome, rising from the basement to a depth of about $1.5 \mathrm{~km}$. This resistive dome would correlate with the magnetic low. Additional data are needed to determine which of the two models, a lava flow (2D) or a dome (3D), is preferred.

\section{Discussion}

MT data identified three distinct resistivity layers on Pahute Mesa and two layers in the Oasis Valley basin region within the upper $5 \mathrm{~km}$ of the earth. These layers are a surface layer (resistive on Pahute Mesa and conductive in Oasis Valley), a conductive second layer (only on Pahute Mesa), and a deep resistive layer. Based on constraints from gravity studies (Mankinen and others, 1999; Hildenbrand and others, 1999), the lower resistive layer is divided into an upper resistive volcanic layer and a more resistive pT basement. Prominent lateral variations within the 


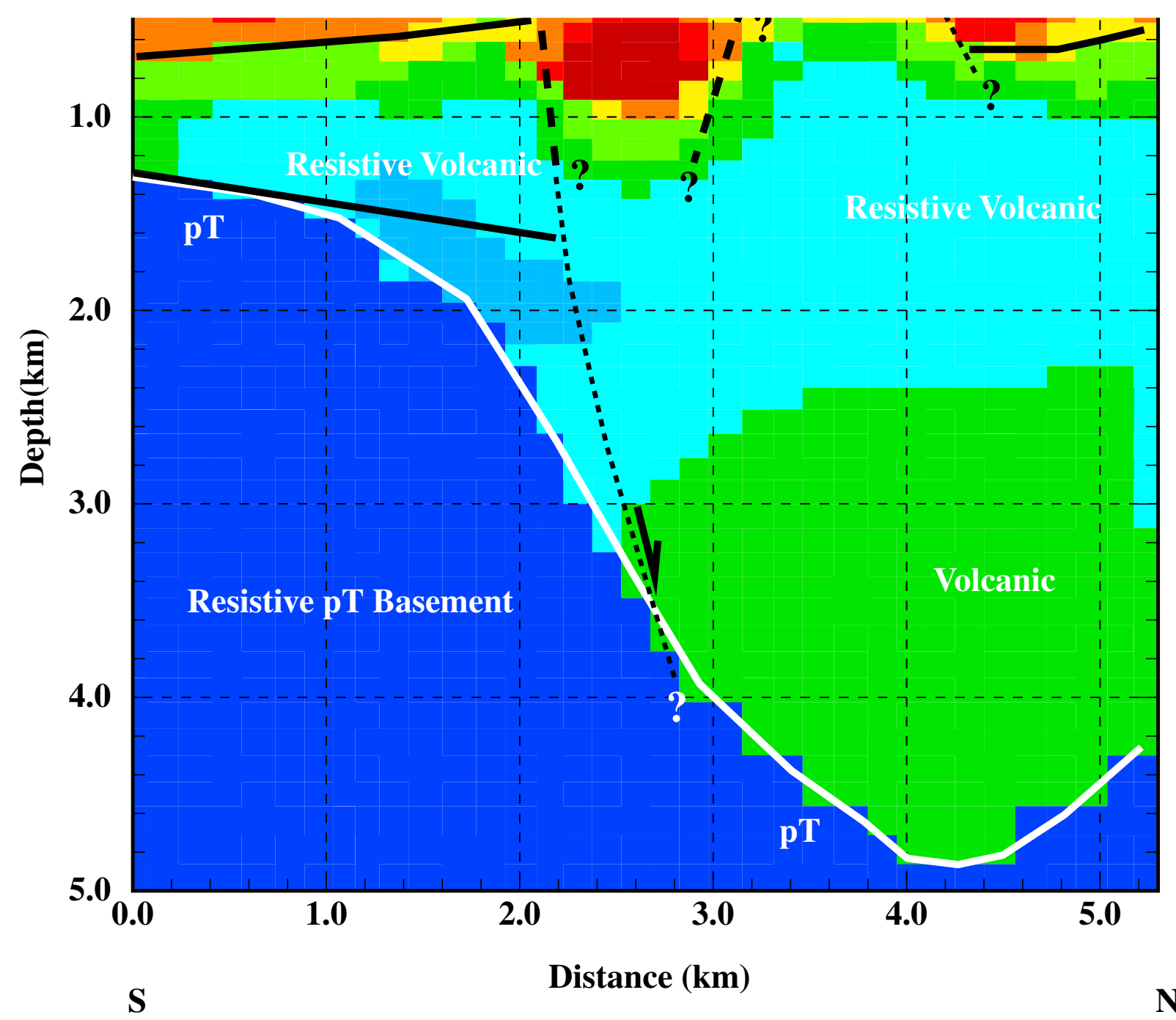

Figure 10: Resistivity cross-section based on the 2D inversion of the MT sounding data along Line 6. The data were collected in the southern end of the Oasis Valley basin (OVBS). The black solid lines represent inferred resistivity layer boundaries. The black long dashed lines are inferred faults. The black short dashed lines are more speculative faults. The while solid line is the basement surface.

volcanic rocks above basement are suggested, especially in the surface and conductive layers. Some of the variations may be related to localized surface inhomogeneities and, at depth, to inferred faults juxtaposing rocks of different electrical properties. Units with low resistivity presumably reflect rocks containing zeolites and clay minerals. Also low resistivities occur within fault zones where fractures in the rock expose greater surface area to groundwater, and thus are more susceptible to alteration (probably clays). These observations, in conjunction with available gravity and magnetic data, appears to reveal several interesting structures that may influence the groundwater flow from Pahute Mesa to Oasis Valley.

The soundings collected on Pahute Mesa detect a thick conductive layer generally extending from near the water table to a depth of roughly $2 \mathrm{~km}$ (Figure 4-6). This conductive layer is probably the zeolite zonation of the volcanic rocks. On Pahute Mesa, zeolite zonation occurs in 
the volcanic layers and can have thickness of up to $1 \mathrm{~km}$ (Hay, 1966; Hoover, 1968). In several locations, the upper section of the zonation contains clay minerals followed by a sequence of zeolite minerals (Hoover, 1968). The existence of this conductive layer makes it possible to detect lateral changes in resistivities at its boundary with the surrounding resistive rocks. In other words, lateral changes in lithology (such as faulting) are clearly expressed along the upper and lower surfaces of the conductive layer as abrupt changes or undulations in resistivity. Conversely, within the conductive zone, the rock resistivity becomes more uniform and structures are harder to define. Thus, several of the near-surface inferred faults in our models may actually extend deep into the conductive layer.

\section{Thirsty Canyon Fault Zone}

The 2-km-wide TCFZ trends SW for at least $35 \mathrm{~km}$ from Pahute Mesa to the Oasis Valley basin (Mankinen and others, 1999). Hildenbrand and others (1999) proposed that this fault zone extends NE of our study area where it is buried beneath alluvial deposits on Gold Flat (Figure 1). They also suggested that this fault zone may continue on trend into the Oasis Valley region or have a left lateral offset within the basin.

Lines 1, 2, and 4 located over the TCFZ detect abrupt lateral changes in resistivity, possibly expressing faults within the zone. Only Line 4 (and possibly Line 2) may have been positioned over the entire TCFZ. Several of the inferred shallow faults (Figures 4, 5, and 7) probably extend down to basement and may be related to the formation of the Silent Canyon caldera (Lines 1 and 2) and Timber Mountain caldera (Line 4). This inference seems to support the interpretation of Hildenbrand and others (1999) that the TCFZ expresses a pre-existing basement fault zone that influenced caldera formation. The MT data appear to show that this basement fault zone extends upward to the near surface. Evidently, the vertical stress related to the collapse of these calderas was accommodated by existing faults of the TCFZ. The absence of a continuous surface expression of the TCFZ from the Oasis Valley basin to Pahute Mesa is probably due to younger volcanic units (e.g., those of the Black Mountain caldera) overlying and masking older faults of the TCFZ.

Resistivities within the TCFZ appear to be lower and more variable than those resulting from zeolitization, possibly suggesting alteration of the volcanic rock (e.g., forming clay minerals) along the fault surfaces. Extensive faulting creates greater surface areas, increases the susceptibility to alteration and thus decreases the rock resistivity. Evidence that fractures are susceptible to alteration is observed in tunnels and from core samples taken from wells where clayey fault gouge and clay minerals commonly sealed fractures in the tuffs (Thordarson, 1965; Winograd and Thordarson, 1975). However, clay alteration was not commonly found in core samples taken from wells on Pahute Mesa (Drellack and others 1997; Prothro, written communication, 1999). Hence, a dense network of open interconnected fractures filled with conductive fluid may be an alternative interpretation for the low resistivities within the TCFZ.

The MT data detect only small variations on the basement surface along Line 4. Because these small undulations would produce subtle or no gravity anomalies, Mankinen and others (1999) state that gravity data cannot detect the TCFZ along Line 4. If the observed basement undulations are real, the MT data suggest that the TCFZ extends into Oasis Valley basin, at least to Line 4 , as a series of faults producing small undulations or offsets on the surfaces of the conductive layer. 


\section{Oasis Valley Basin}

The Oasis Valley basin is a rectangular area on the west side of the exposed part of the SWNVF caldera complex (C.J. Fridrich, USGS, written communication, 1999). Because of poor exposure in many areas, the boundaries of this basin are defined by geophysical methods. The western and southern boundaries of Oasis Valley basin are defined by the Hogback and southern structural margin of the Rainier Mesa caldera, respectively. The northwestern and eastern edges of the basin are formed by the southern margin of the Black Mountain and the western margin of the Transvaal Hills, respectively. Internal and marginal structures, such as the TCFZ, the source of the CPL, and OVBS (Figure 1) are apparent on magnetic and gravity maps (Mankinen and others, 1999). Lines 5 and 6 cross major structures of the Oasis Valley basin (C.J. Fridrich, USGS, written communication, 1999).

The Colson Pond lineament (CPL), named by Fridrich (USGS, written communication, 1999), is an EW-striking feature identified with gravity and magnetic data (Hildenbrand and others, 1999; Mankinen and others, 1999). Fridrich (USGS, written communication, 1999) propose that the CPL is a growth fault formed during the deposition of the Timber Mountain rocks or a strike-slip fault that offsets deep basin sections against outer basin sections. Large changes in stratigraphic thicknesses are probably present across this structure (C.J. Fridrich, USGS, written communication, 1999). The MT data (Figure 8) support a south-dipping fault in the vicinity of the CPL. The thickening of the low resistivity layer associated with the fault zone is probably due to altered volcanic rock and sediment. The low resistivity values associated with the surface layer are probably due to the saturated and altered alluvium.

The southern structural margin of the Rainier Mesa caldera appears to coincide with the southern boundary of the Oasis Valley basin (Figure 1). This structure may delineate an accommodation fault or zone that transfers strain between different structural domains (C.J. Fridrich, USGS, written communication, 1999). The MT model (Line 6, Figure 9) supports the basin thickness model of Hildenbrand and others (1999) with up to 3-3.5 km of relief on basement in the southern part of the basin. However, the MT data can be modeled with a steeper fault $\left(\operatorname{dip} \sim 75^{\circ}-80^{\circ}\right.$ ) along the southern margin of the basin. The fault zone probably extends into the overlying volcanic rocks to a depth of at least $500 \mathrm{~m}$ due to a shallow conductive body lying directly above the faulted basement surface (Figure 9). We propose that this conductive source is related to alteration along a highly fractured zone.

\section{Buckboard Mesa Lineament}

A ESE-striking magnetic lineament (Grauch and others, 1997) extends from the eastern side of the Black Mountain caldera (BM, Figure 1) approximately $30 \mathrm{~km}$ eastward along the northern boundary of the Timber Mountain caldera (TMC, Figure 1). The central part of this lineament, called the BML (Mankinen and others, 1999), coincides with the topographic wall of the Rainier Mesa caldera (Grauch and others, 1997). In the area of Line 3 (Figure 3), Grauch and others (1997) indicated that moderately positively magnetized formations (Ammonia Tanks or Topopah Spring Tuffs) abut against highly negatively magnetized rhyolite of Benham (post Tiva Canyon).

In the vicinity of the BML, a proposed fault offsets the conductive layer (at m08, Figure 6). This inferred fault probably is related to the topographic wall of the Rainier Mesa caldera. Thus, the increase in the thickness of the resistive surface layer along the southern part of the profile may 
reflect a thick zone of welded tuffs that ponded south of the topographic wall. The intensely conductive source between site m08 and m09 (Figure 6) is likely a local three-dimensional (3D) body. On the magnetic anomaly map (Mankinen and others, 1999), a 1-km-wide intense anomaly spatially coincides with the conductive source. Moreover, MT skew data (Schenkel, 1998) suggest the presence of a $3 \mathrm{D}$, local source.

\section{Hydrologic Implications}

Groundwater flow beneath Pahute Mesa occurs through interconnected fault and joint systems in the Tertiary volcanic rock units (Blankennagel and Weir, 1973). From hydraulic well tests on Pahute Mesa, Blankennagel and Weir (1973) proposed that the rock units easily transmitting water are rhyolite lavas while the zeolitized tuffs have very low permeabilities (Blankennagel and Weir, 1973). Lava, which is a relatively impermeable rock, transmits water readily in Pahute Mesa due to the numerous connected fractures that tend to remain open. Welded tuffs also are found to be good aquifers since they have high fracture permeability and moderate interstitial permeability if unaltered (Blankennagel and Weir, 1973, Lazczniak and others, 1996). Records from holes drilled in the welded tuffs and lava flows suggest open and interconnected network of fractures because mud circulation was repeatedly lost during drilling. These fractures are usually formed in response to tensional forces active during the cooling phase of the flow. Winograd and Thordarson (1975) found that fractures make up a small percentage $(<2 \%)$ of the volume in core samples but appear to control the transmissibility of rocks. Most of the ash-fall and nonwelded ash-flow tuffs in the saturated zone are zeolitized. Water flowing in zeolitized units are also through fractures (Thordarson, 1965). However, fractures in these rock types tend to heal more readily and are more susceptible to alteration, reducing its transmissivity (Winograd and Thordarson, 1975; Blankennagel and Weir, 1973; Lazczniak and others, 1996).

Hildenbrand and others (1999) proposed that basement in the study area consists mainly of clastic sedimentary rock rather than carbonate rock. Clastic sedimentary rock, particularly the fine-grained quartzite and argillite at Bare Mountain and Bullfrog Hills, is resistant to fracturing. If fractured, they tend to be disconnected. Thus basement probably is a barrier to groundwater flow.

Synder (1968) and Blankennagel and Weir (1973) pointed out that on Pahute Mesa the rock units that easily transmit water through open interconnected fracture (rhylotic lavas and densely welded tuffs) are relatively resistive. The rocks with poor transmissivity due primarily to zeolitization and alteration (sealing fractures and pore space) of the ash-fall and nonwelded ashflow tuffs are electrically conductive. Using these relations, one may infer subsurface structures that may influence groundwater flow based on the distribution of the electrical resistivity. Here, we explore the possible effects of the interpreted structures on the groundwater flow from Pahute Mesa to the Oasis Valley basin.

\section{Thirsty Canyon Fault Zone}

The concept of southwesterly flow of groundwater from Pahute Mesa towards Oasis Valley basin is based on a SW-trending flow barrier (WLD, Figures 1 and 2) proposed by Blankennagel and Weir (1973) from hydraulic gradients taken from contoured water level data. They suggested that this barrier juxtaposes low permeable rock on the west against more permeable rock on the 
east. Water chemistry also supported this concept (Blankennagel and Weir, 1973; Laczniak and others, 1996; Kilroy and Savard, 1995). This barrier is spatially near if not actually within the TCFZ. Because the TCFZ juxtaposes rocks of different permeabilities, it is likely to act as a barrier to transverse groundwater flow.

Three MT profiles cross the TCFZ, two on Pahute Mesa and one in the Oasis Valley basin near its terminus. Along each profile the TCFZ appears to be characterized by very low resistivities and near-vertical discontinuities assumed to define faults. The low resistivities $(<50 \Omega$-m) may reflect alteration (possibly clays) along fractured rock. Clay minerals form if the cations released by hydrogen exchange are flushed (Hoover, 1968). This requires water flowing through fractures at the time the clay minerals were formed. Hence, it is likely that the conductive TCFZ is highly fractured and acts as or at one time was a conduit for southward flow of groundwater. Thus, the fractures within the TCFZ may act as a barrier or a conduit to groundwater flow, depending on the degree of alteration and its effect on permeability. However, clay alteration was not common in samples taken from wells at Pahute Mesa (Warren and others, 1999; Prothro, written communication, 1999). From 20 samples in cores from 8 wells on Pahute Mesa, Drellack and others (1997) typically found that the clays formed a thin lining on the fracture walls. Based on the uncommon occurrence of clays found in samples from well on Pahute Mesa, the electrically conductive TCFZ may be due to a higher density of open, interconnected fractures filled with conductive groundwater. This implies that the TCFZ would act as a conduit for southward flow of groundwater from Pahute Mesa to Oasis Valley. A drill hole within the TCFZ would resolve which interpretation is preferred.

Line 1 (Figure 4) appears to extend over the eastern part of the TCFZ which presumably continues west beyond the profile. Although the western margin of the TCFZ is represented in the cross-section of Line 2, its eastern margin may lie at or beyond the end of the line. South in the Oasis Valley basin, Line 4 seems to show that the TCFZ is roughly $2.5 \mathrm{~km}$ wide. From this profile, the proposed groundwater flow related to the TCFZ may extend SW to, at least, latitude $37^{\circ} 05^{\prime}$. The combined effect of shallowing of the impermeable basement and channeling of water along the TCFZ toward Oasis Valley basin probably results in a shallow water table and in springs where the TCFZ meets the fault zone associated with the CPL. Thus, the MT data appear to support the conclusion of Hildenbrand and others (1999) that the TCFZ acts a barrier to deep flow and may channel groundwater to the Oasis Valley basin. Recent water chemistry analysis of isotopes and major ion concentration from wells on Pahute Mesa and in Oasis Valley (Kilroy and Savard, 1996; Thomas, 1998, written communication) also supports this conclusion due to a distinct correlation of the groundwater chemistry from Pahute Mesa and that in the Oasis Valley basin.

\section{Buckboard Mesa Lineament}

Line 3 (Figure 6) crosses the BML and presumably a shallow topographic wall related to Timber Mountain caldera. The MT data may delineate a south-dipping fault forming a thick resistive surface layer (south of the fault). Because this resistive layer is likely associated with densely welded tuffs related to this caldera, the transmissivity of the rocks in the upper $2 \mathrm{~km}$ will probably increase from north to south across the fault zone since aquifers are generally found in welded tuff layers. 


\section{Oasis Valley Basin}

The NS profiles (Lines 5-6; Figures 8-9) show a resistive, probably unaltered volcanic second layer (300-700 $\Omega \cdot \mathrm{m}$ ) underlying a conductive layer. The inferred fault zone at CPL (Figure 8) and the impermeable basement appear to pinch the resistive volcanic layer in the vicinity of the fault zone, which may affect groundwater flow particularly if a high degree of alteration sealed the fractures. The conductive nature of the surface layer in the fault zone indicates water movement along this inferred fault zone, possibly towards Colson Pond. On the southern end of Oasis Valley basin (Line 6; Figure 9), a steep north-dipping fault zone offsets basement and younger volcanic rock at shallow depths $(\sim 500 \mathrm{~m})$. The large offset of basement along the southern margin of the Oasis Valley basin probably reduces southward groundwater flow as basement is assumed to be relatively impermeable. Altered volcanic and sedimentary rocks above the fault zone may act as a barrier diverting groundwater to the SW toward Beatty. If the EW barrier is not present, groundwater may flow south into Crater Flat.

\section{Conclusion}

MT data collected in the Pahute Mesa-Oasis Valley basin region define several structures possibly influencing groundwater flow. Using observed relations of the electrical and hydrological properties of the volcanic rocks, structures that control groundwater flow, such as faults, may have been tentatively identified. The NE-trending TCFZ, being electrically conductive, may represent a groundwater flow conduit channeling water from Pahute Mesa southwestward into the Oasis Valley basin. In the southern end of the Oasis Valley basin, a fault zone that may have

altered the surface layer and underlying resistive volcanic layer may also be a possible barrier to groundwater flow. Future research topics should include determining the flow path from the Oasis Valley basin (e.g., SW towards Beatty or south into Crater Flat).

\section{Acknowledgements}

We thank Jerry Magner and Doug Trudeau (USGS, Las Vegas) for arranging the logistics on the NTS and Nellis Air Force Range and for facilitating our work there. We are extremely grateful to Don Schaefer, Jay Sampson, Jackie Williams, Bob Bisdorf, Roy Kipfinger, Kip Allander, Jeff Davidson, and Ted Asch (EMI) who assisted in the collection of the field data on Pahute Mesa and in Oasis Valley. We also wish to thank EMI for their technical support and access to their facilities during the acquisition and processing of the data. We are indebted to Mike Hoversten (LBL) for his time and knowledge of MT data analysis and his software made available for use. Discussions with Mike Hoversten and Frank Morrison (U.C. Berkeley) were very useful in the analysis and interpretation of the MT data. Conversations with Ted McKee, Chris Fridrich, Randy Laczniak, and Jim Thomas greatly improve our models and conclusions, although their accuracy are solely the responsibility of the authors. We also acknowledge the useful perspectives and thoughtful comments on this manuscript by: Lance Protho, Sig Drellack, Margaret Townsend, Ward Hawkins, Bruce Hurley, Gayle Palowski and Paul Kasameyer. We also want to thank Paul Stone for his editorial comments. This work is part of an interagency effort between the USGS and the U.S. Department of Energy and was funded through the Interagency Agreement DE-AI08-96NV11967. 


\section{References}

Blankennagel, R.K. and Weir, J.E., Jr., 1973, Geohydrology of the eastern part of Pahute Mesa, Nevada test Site, Nye County, Nevada: U.S.G.S. Professional Paper 712-B, 35p.

Cagniard, L., 1953, Basic theory of the magneto-telluric method of geophysical exploration: Geophysics, 18, p. 605-635.

Drellack, Jr., S.L., Prothro, L.B., Roberson, K.E., Schier, B.A., and Price, E.H., 1997, Analysis of fractures in volcanic cores from Pahute Mesa, Nevada Test Site: DOE/NV/11718-160, Las Vegas, NV.

Ekren, E.B., 1968, Geological setting of Nevada Test Site and Nellis Air Force Range, in Eckel, E.B., ed., Nevada Test Site: Geological Society of America, Memoir 110, p. 11-20.

Furgerson, R.B., 1982, Remote-reference magnetotelluric survey, Nevada Test Site and vicinity, Nevada and California, with an introduction by D.B. Hoover: U.S.G.S. Open-File Report $82-465,156 \mathrm{p}$.

Gamble, T.D., Goubau, W.M., and Clarke, J., 1979, Magnetotellurics with remote reference: Geophysics, 44, p. 53-68.

Grauch V.J.S., Sawyer, D.A., Fridrich C.J., and Hudson M.R., 1997, Geophysical interpretations west of and within the northwestern part of the Nevada test site: U.S.G.S. Open-File Report 97-476, 45p.

Hay, R.L., 1966, Zeolites and zeolitic reactions in sedimentary rock: Geological Society of America, Special Papers number 85, 130p.

Hildenbrand, T.G., Langenheim, V.E., Mankenin, E.A., and McKee, E.H., 1999, Inversion of gravity data to define the pre-Tertiary surface of the Pahute Mesa-Oasis Valley region, Nye County, Nevada: U.S.G.S. Open File Report 99-49, 26p.

Hoover, D.L., 1968, Genesis of Zeolites, Nevada Test Site, in Eckel, E.B., ed., Nevada Test Site: Geological Society of America, Memoir 110, p. 275-284.

Hoover, D.B., Hanna, W.F., Anderson, L.A., Flanigan, V.J., and Pankratz, L.W., 1982a, Geophysical studies of the Syncline ridge area, Nevada Test Site, Nye County, Nevada:

U.S.G.S. Open File Report 82-145, 55p.

Hoover, D.B., Chornack, M.P., Nervick, K.H., and Broker, M.N., 1982b, Electrical Studies at the proposed Wahmonie and Calico Hills nuclear waste sites, Nevada Test Sites, Nye Co., Nevada: U.S.G.S. Open-File Report 82-466, 45p.

Keller, G.V., 1987, Rock and mineral properties, in Electromagnetic Methods in Applied Geophysics-Theory: Nabighian, M.N., ed., Society of Exploration Geophysicists, Tulsa, Ok, v 1, p. 13-51.

Keller, G.V. and Frischknecht, F.C., 1966, Electrical methods in geophysical prospecting: Pergammon Press, New York, 517p.

Kilroy, K.C. and Savard, C.S., 1995, Geohydrology of Pahute Mesa-3 test well, Nye County, Nevada: U.S.G.S. Water Resources Investigations Report 95-4239, 37p.

Klein, D.P., 1995, Chapter 4: Regional magnetotelluric investigations, in Oliver, H.W., Ponce, D.A., and Hunter, W.C., eds., Major results of geophysical investigations at Yucca Mountain and vicinity, southern Nevada: Open-File Report 95-74, p. 73-97.

Laczniak, R.J., Cole, J.C., Sawyer, D.A., and, Trudeau, D.A., 1996, Summary of hydrogeologic controls on ground-water flow at the Nevada Test Site, Nye County, Nevada: U.S.G.S. Water-Resources Investigations Report 96-4109, 59p. 
Mankinen, E.A., Hildenbrand, T.G., Roberts, C.W., and Davidson, J.G., 1998, Principle facts for new gravity stations in the Pahute Mesa and Oasis Valley areas, Nye County, Nevada: U.S.G.S. Open-File Report 98-498, 14p.

Mankinen, E.A., Hildenbrand, T.G., Dixon, G.L., McKee, E.H., Fridrich C.J., and Laczniak, R.J., 1999, Gravity and magnetic study of the Pahute Mesa and Oasis Valley region, Nye County, Nevada, U.S.G.S. Open File Report 99-303, 57p.

Maldonado, F., Muller, D.C., and Morrison, J,N., 1979, Preliminary geological and geophysical data of the UE25a-3 exploratory drill hole, Nevada Test Site, Nevada: USGS-1543-6, $47 \mathrm{p}$.

Noble, D.C., Weiss, S.I., and McKee, E.H., 1991, Magmatic and hydrothermal activity, caldera geology, and regional extension in the western part of the southwestern Nevada volcanic field, in Raines, G.L., Lisle, R.E., Schaefer, R.W., and Wilkinson, W.H., eds., Geology and ore deposits of the Great Basin, Symposium Proceedings: Reno, Geological Society of Nevada, p. 913-934.

Olhoeft, G.R., 1981, Electrical properties of granite with implications for the lower crust: Journal Geophysical Research, 86, p. 931-936.

Olhoeft, G.R., 1980, Electrical properties of rocks, in Physical Properties of Rocks and Minerals: Touloukian, Y.S., Judd, W.R., and Roy, R.F., eds., McGraw-Hill, New York, p. 257-330.

Palacky, G.J., 1987, Resistivity characteristics of geologic targets, in Electromagnetic Methods in Applied Geophysics-Theory: Nabighian, M.N., ed., Society of Exploration Geophysicists, Tulsa, Ok, v 1, p. 53-129.

Plouff, Donald, 1966, Magnetotelluric soundings in the southwestern United States: Geophysics, v. 31, p.1145-1152.

Sawyer, D.A., Fleck, R.J., Lanphere, M.A., Warren, R.G., Broxton, D.E., and Hudson, M.R., 1994, Episodic volcanism in the southwest Nevada volcanic field: Revised stratigraphic framework, Ar40/Ar39 geochronology, and implications for magnetism and extension: Geological Society of America Bulletin, 106, no. 10, p. 1304-1318.

Schenkel, C.J., 1998, Magnetotelluric data in the Pahute Mesa and Oasis Valley areas, Nye County, Nevada: U.S.G.S. Open-File Report 98-504, 70p.

Snyder, R.P., 1968, Electric and caliper logs as lithologic indicators in volcanic rocks, Nevada Test Site: in Eckel, E.B., ed., Nevada Test Site: Geological Society of America, Memoir 110, p. 117-124.

Thordarson, W., 1965, Perched ground water in zeolitized-bedded tuff, Rainier Mesa and vicinity, Nevada Test Site, Nevada: U.S.G.S. Trace Elements Investigations Report TEI-862, 90p.

Tikhonov, A.N., 1950, On determining electrical characteristics of the deep layers of the earth's crust: Doklady, 73, p. 295-297.

Torres-Verdin, C., 1991, Continuous profiling of magnetotelluric fields: Ph.D. thesis, University of California, Berkeley.

Torres-Verdin, C. and Bostick, F.X., Jr., 1992, Principles of spatial surface electric field filtering in magnetotellurics; Electromagnetic array profiling (EMAP): Geophysics, 57, p. 603622.

U.S. Department of Energy, 1994, United States nuclear tests; July, 1945 through September, 1992; U.S. Department of Energy, Nevada Operation Office, DOE/NV-209 (rev 14), 105 p. 
Vozoff, K., 1972, The magnetotelluric method in the exploration of sedimentary basins: Geophysics, 37, p. 98-141.

Vozoff, K. (editor), 1986, Magnetotelluric Methods: Geophysics reprint series no. 5, Society of Exploration Geophysicists, Tulsa, OK, 763p.

Vozoff, K., 1991, The magnetotelluric method: in Nabighian, M.N., Ed., Electromagnetic Methods in Applied Geophysics, v. 2, Application, Part B, Society of Exploration Geophysicists, Tulsa, p. 641-711.

Wahl, R.R., Sawyer, D.A., Minor, S.A., Carr, M.D., Cole, J.C., Swadley, W.C., Laczniak, R.J., Warren, R.G., Green, K.S., and Engle, C.M., 1997, Digital geologic map of the Nevada Test Site area, Nevada: U.S.G.S. Open-File Report 97-140, scale 1:120,000.

Warren, R.G., Sawyer, D.A, Byers, Jr., F.M., and Cole, G.L., 1999, A petrographic/geochemical database and structural framework for the Southwestern Nevada Volcanic Field: available from the National Geophysical Data Center at http://queeg.ngdc.noaa.gov/seg/geochem/ swnvf.

Winograd, I.J. and Thordarson, W., 1975, Hydrogeologic and hydrochemical framework, SouthCentral Great Basin, Nevada-California, with special reference to the Nevada Test Site: U.S.G.S. Professional Paper 712-C, 126p.

White, A.F., 1979, Geochemistry of ground water associated with tuffaceous rocks, Oasis Valley, Nevada: U.S.G.S. Professional Paper 712-E, 25p.

White, A.F., Claassen, H.C., and Benson, L.V., 1980, The effects of dissolution of volcanic glass on the water chemistry in a tuffaceous aquifer, Rainier Mesa, Nevada: U.S.G.S. Water Supply Paper 1535-Q, 34p. 


\section{Appendix A}

\section{Concept of Magnetotellurics}

The fundamentals of magnetotellurics (MT) as an exploration method were developed by Tikhonov (1950) and Cagniard (1953), in context of one-dimensional (1D) resistivity models. Papers by Vozoff (1972, 1986, and 1991) and Furgerson (1982) give overviews of this technique for $2 \mathrm{D}$ and 3D situations. MT is an electromagnetic sounding technique that uses measurements of the natural surface electric $(\mathrm{E})$ and magnetic $(\mathrm{H})$ fields to infer the subsurface electrical resistivity distribution.

The natural sources of MT fields come from lightning discharges and magnetospheric current systems set up by solar activity. These sources create a spectrum of EM fields in the frequency band $10^{-4}$ to $10^{4} \mathrm{~Hz}$, which provide information to delineate structures at depth from a few tens of meters to the upper mantle at a few tens of kilometers. MT data at various frequencies provide a means to distinguish spatial variations in resistivity vertically and laterally. The EM field penetration, which decays exponentially, is related to the frequency and resistivity of the medium. Higher frequencies map the near-surface resistivity distribution. Lower frequencies which penetrate farther provide information on deeper structures. However, lateral inhomogeneities will also influence these measured fields at equivalent distances from the measurement point.

Time-varying H-fields, which behave almost like plane waves at the surface of the earth, are produced from the natural sources. Because of the high refractory index at the air-earth interface, most of the energy is reflected but a small amount is propagated vertically downward into the earth. Through Faraday's Law the H-fields produce an electromotive force (emf) in the conducting earth that causes electric currents to flow within the earth. Spectral estimation techniques are used to obtain a frequency and space dependent, $2 \times 2$ surface impedance matrix, $Z$, relating linearly orthogonal E-field and $\mathrm{H}$-field values measured at the same point on the surface of the earth. By sampling $\boldsymbol{Z}$ from a number of locations within the survey area, one can infer the distribution of subsurface electrical resistivity.

For a 1D layered half-space, the off-diagonal elements of the surface impedance tensor ( $Z x y$ and $Z x y)$ are the same. However, if the ground is inhomogeneous, the surface impedance components are different. If the surface impedance tensor is rotated so that the diagonal elements ( $Z x x$ and $Z y y$ ) are minimized (close to zero), the off-diagonal elements, $Z x y$ and $Z y x$, are called the principle impedances and the angle of rotation is the impedance strike direction. The impedance strike direction and its orthogonal complement make up the principle axes; the impedance strike has an inherent $90^{\circ}$ shift ambiguity that is usually resolved from the Tipper data (see Vozoff, 1991), or from the frequency relationships of the various impedance elements.

If one assumes that a survey profile direction (x-axis) is collected orthogonal to the geoelectric strike direction (y-axis), the two modes (orthogonal components) of the surface impedance are along the principle axes. For a 2D structure, the Zxx and Zyy components are zero. The surface impedance is composed of two modes. One mode is where the electric field is parallel with the electrical strike direction and is called the transverse electric (TE) mode. The other, the transverse magnetic TM mode, is where the electric field is along the profile direction (orthogonal to the strike). The TM mode is sensitive to lateral discontinuities since the electric field will change across a lateral boundary. In general, the two impedance components are presented as sounding 
curves showing the apparent resistivities modes, $\rho_{T M}$ and $\rho_{T E}$, and impedance phases $\left(\theta_{T M}\right.$ and $\theta_{T E}$ ) for the two modes as a function of frequency as sounding curves. If the data express a layered medium, the apparent resistivity $\left(\rho_{T M}\right.$ and $\left.\rho_{T E}\right)$ are the same. However, if the two curves diverge, a 2D or 3D structure is likely present. The skew (see Vozoff, 1991), which is a function of Zxx and $Z y y$, can be used to determine if the structure is 2D or 3D. In theory, the skew should be zero (near zero) for a 2D or 1D medium.

\section{Factors Influencing the Electrical Properties}

A given geologic unit can have changes in resistivity due to variations in the pore fluid resistivity and the fluid volume, both of which are controlled by various geologic processes. Ionic exchange between minerals and pore fluids at the pore interface is an important factor in the resistivity of the rock (Keller and Frischknecht, 1966; Olhoeft, 1980 and 1981, Keller 1987, and Palacky, 1987). Increased ionic content and dissolved solid concentrations in the pore fluid will reduce the resistivity of saturated rocks. Pore space in the rock is affected by two main factors. The first factor is the emplacement process which affects porosity (thus the amount of water present); deposits that have greater porosity tend to have lower resistivity. The second factor is related to geologic processes such as alteration or mineralization. These processes can have a significant effect on the resistivity of the rock by filling the pore spaces and changing the ionic content of the pore fluid.

The dominant ionic constituents of the groundwater in the vicinity of the TCL (beneath western part of Pahute Mesa) are sodium (cation) and bicarbonates (anion) (Blankennagel and Weir, 1973). The relatively high concentration of these ions is probably due to the volcanic tuffs that comprise the principal volcanic rock types in the saturation zone of this area. In addition to the abundant amounts of bicarbonates, sulfates and chloride anions exist in relatively large amounts. The concentration of chemical constituents in the groundwater in this area is relatively uniform and greater than that in the eastern part of Pahute Mesa. The dissolved solids in the water ranges from 206 to 336 milligrams/liter (mg/l) and average $280 \mathrm{mg} / \mathrm{l}$. The high amounts of ions and dissolved solids produces relatively conductive groundwater where the specific conductance of the groundwater ranges from $\sim 300$ to $>500 \mu \mathrm{S} / \mathrm{cm}(0.3-0.5 \mathrm{~S} / \mathrm{m}$ or $2.0-3.3 \Omega \cdot \mathrm{m})$.

The rhyolitic volcanic rocks typical in the study area are lava flows, bedded ash-fall tuffs, and ash-flow tuffs with various degrees of welding. In a water-saturated environment, the volcanic rocks exhibiting greater porosity tend to be less electrically resistive. In general, bedded ash-fall tuffs generally exhibit porosities $(\geq 40 \%)$ greater than flow rocks (Winograd and Thordarson, 1975); consequently ash-fall tuffs tend to have the lowest resistivity. Additionally, these rocks are the most susceptible to alteration and secondary mineralization. In the ash-flow rocks, as welding increases, pore space decreases resulting in higher resistivities. Winograd and Thordarson (1975) found that nonwelded tuffs have porosities of up to $40 \%$ while the porosity of densely welded tuffs range from $4 \%$ to $13 \%$. Thus, resistivity will increase as the welding in ash-flow tuffs increases. Lava flows with very little porosity (2-15\%) (Blankennagel and Weir, 1973) generally have the highest resistivities. The fractures in the lavas and densely welded tuffs will increase the effective permeability of the rock.

At the NTS, vitric rock reacts with the groundwater to produce zeolites, cristobalite, quartz, Kfeldspar, and clay minerals (Hoover, 1968). The alteration of the volcanic rocks on Pahute Mesa 
occurs in the presence of fluid (Hoover, 1968). Vitric rocks can form clay minerals only if they are unsaturated and drained rapidly; while zeolite minerals require a saturated environment to form (Hoover, 1968). Zeolites precipitate from solution typically into the pore spaces or cavities of the tuffs (Hay, 1966). On Pahute Mesa, a common alteration mineral associated with zeolites is montmorillonite (clay) (Thordarson, 1965; Hoover, 1968, White and others, 1980). Zeolite and clay minerals decrease the rock resistivity due to the increase in surface conduction arising from the ionic exchange between the fluid and minerals at the pore-wall interface. Minerals exhibiting cation exchange capacity (the quantity of exchangeable cations attached to a mineral) tend to have lower resistivities. Clay minerals are commonly known to have high exchange capacities. Zeolite minerals have cation exchange capacity greater than some clay minerals (Keller and Frischknecht, 1966). In fact, all fine-grained minerals including quartz have an appreciable cation exchange capacity and the exchange capacity is larger for finer grained particles (Keller and Frischknecht, 1966). Since all rocks possess some exchange capacity, the resistivity of the fluid in a pore space will always be decreased by ions supplied by desorption (Keller and Frischknecht, 1966). Thus, as the amount of zeolites and clay minerals increase, resistivity decreases in volcanic rock.

From electric well logs, Snyder (1968) and Blankennagel and Weir (1973) showed good relations between volcanic rock types on Pahute Mesa and representative electrical resistivities.

Resistivities of the rhyolitic lavas range from over $225 \Omega \cdot \mathrm{m}$ to more than $1,000 \Omega \cdot \mathrm{m}$. The densely welded tuffs have resistivities in the same range as those of the rhyolitic lavas. Most resistivities of moderately welded tuffs are between $100 \Omega-\mathrm{m}$ to $225 \Omega-\mathrm{m}$. Resistivities of relatively impermeable zeolitized tuffs are generally $<100 \Omega \cdot \mathrm{m}$. The resistivities of vitric ash-fall tuffs, nonwelded to slightly welded ash-flow tuffs, and tuffaceous sediments are similar to those of zeolitized units. The lowest resistivities occurred in intervals altered by clay minerals.

\section{Data}

The model fit to the field data for Lines 1 to 6 are shown in Figures A-1 to A-6, respectively. In the sounding curves (apparent resistivity and impedance phase), the field data for the TM and TE modes are represented by black lines with squares and circles, respectively. Dark gray (TM) and light gray (TE) lines show the calculated responses of the models for each MT site (plot title).

Figure A-1 shows that the TM mode of the model closely simulate the field data. Several other models based solely on the TM data result in the same general structure. The TE mode data have a poorer fit, especially near the area of the vertical conductive block (p22-p23). This may indicate that the conductive block may be more conductive and/or extensive than shown on the resistivity cross-section.

The model response matched the field data of Line 2 for the TM mode (Figure A-2). The TE mode data have a poorer fit, especially near the area of the BML (b02-b04). Since the data are rotated to maximize the response of the TCFZ, the source of the BML may produce a 3D effect on the data. At the sites removed from the BML the simulations of the TE mode match the field data well. The misfit of the data and simulations in the phase at the low frequencies indicate that the model of the deep conductor is too resistive or too deep. However, this misfit does not affect the upper section of the model.

The results for Line 3 show that the apparent resistivity and impedance phase for the TM and TE 
modes are matched well (Figure A-3). The responses from the model were able to closely match the field data particularly with the TM mode. Again, the TE mode data have a slightly poorer fit especially at the low frequencies at site m08 indicating a small local near-surface inhomogeneity.

The simulated and field data are plotted in Figure A-4 for Line 4. The simulated TM apparent resistivity fit the field data well. The TE counterparts match the field data except for the low frequencies of n01 and n02. The simulated phase does not match the field result well.

Figure A-5 shows the model fit the field data well for the TM mode (both apparent resistivity and impedance phase). For the TE mode only the apparent resistivity fit the data while the impedance phase has a poor match, especially at n14 and n13. The TE data are very noisy as seen by the large error bars.

Again, the TM mode of the model and field data fit well (Figure A-6). For the TE mode, the apparent resistivity of the model simulated the field data while the impedance phase has a poorer fit. The TE data are very noisy as seen by the large error bars. 

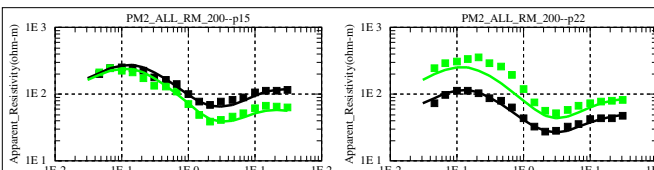

Frequency(H)

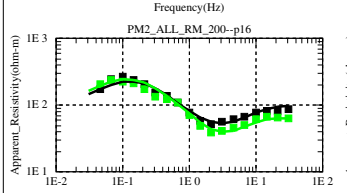

Frequency(Hz)
PM2_ALLRM_200-p22
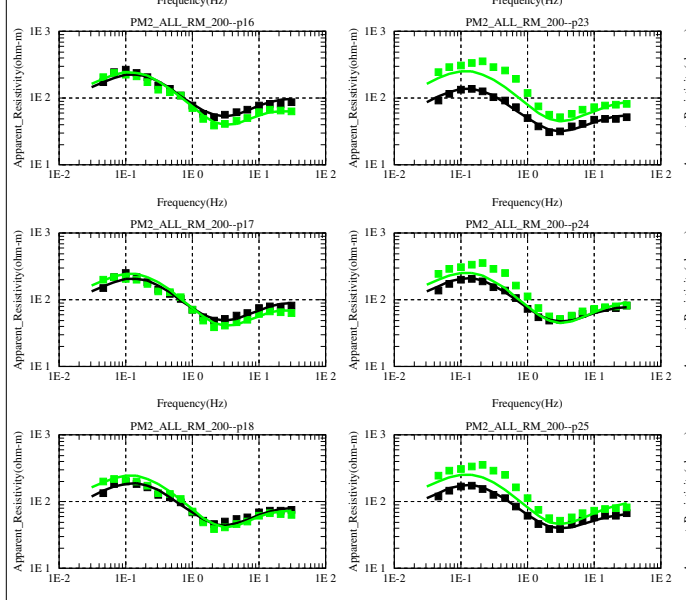

Frequency(Hz)
M2_ALL_RM_20--p26

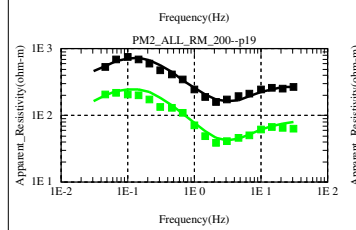

Frequency(tha)

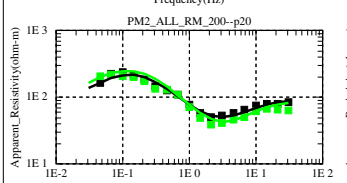

Frequency(Hz)
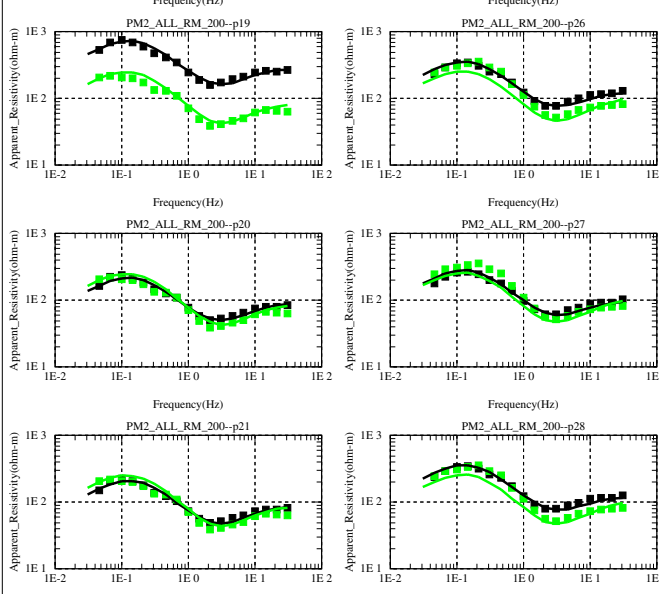

Frequeny(Hz)
PM2_ALL RM-200-p27

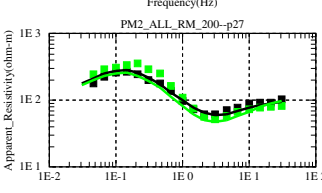

Frequency(Hz)
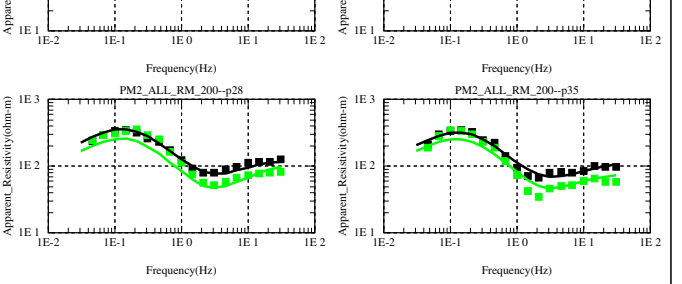

parent Resistivity

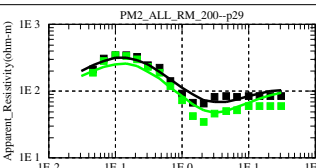

Frequency (H)
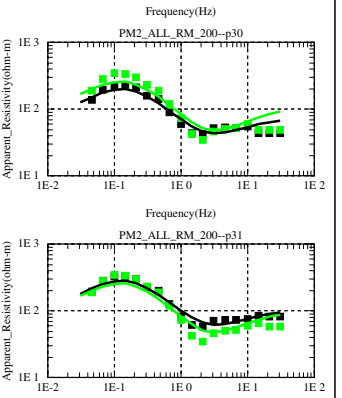

Fienemeny(t)

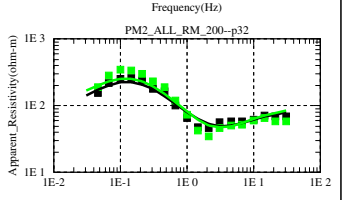

Frequency(Hz)
M2_ALL_RM_200-p33

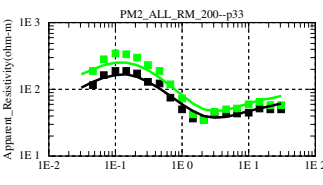

Frequency(Hz)
PM

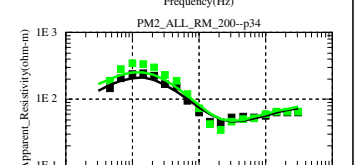

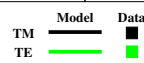
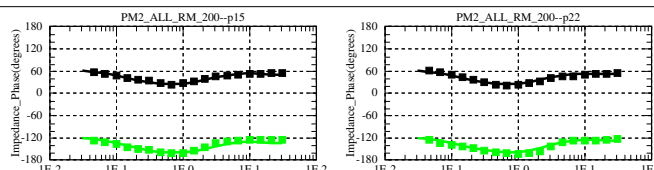

Frequency(Hz)

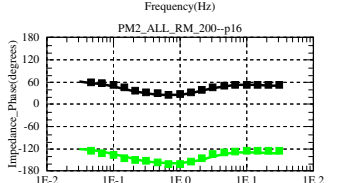

Frequency(Hz)

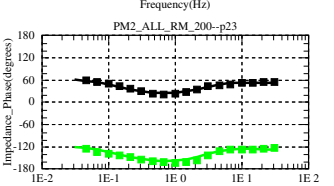

Frequeneny $($ H)
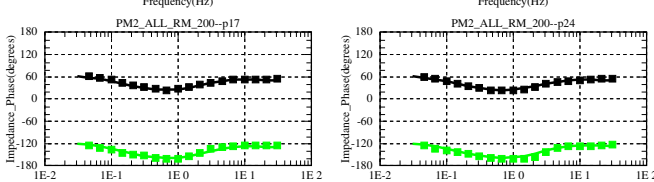

Ficepency(H)
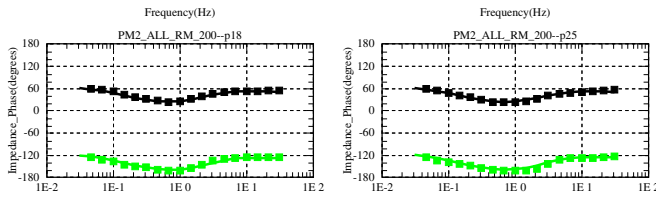

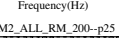
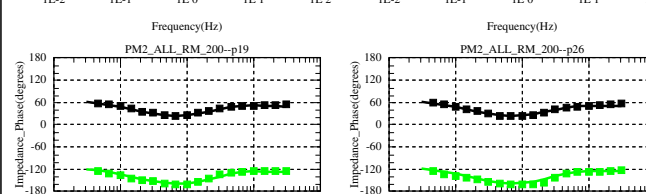

Frequency-Hz)
PM2_AlL_RM_200-P26

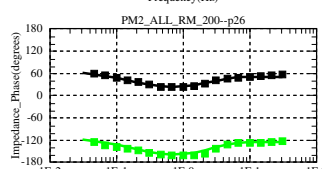

Frequeneny(th)

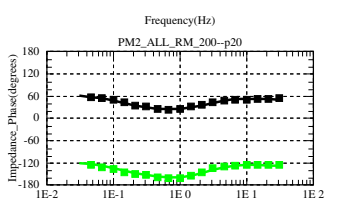

Frequeny(H)

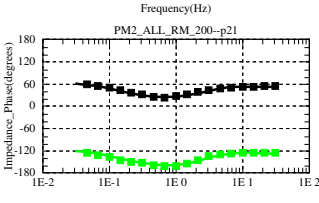

IE0
Frequeney(Hz)

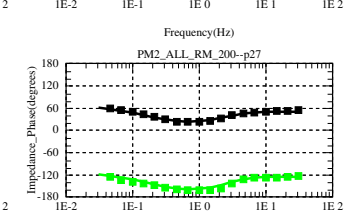

Frequency(t)

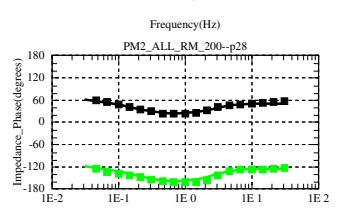

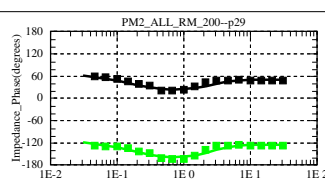
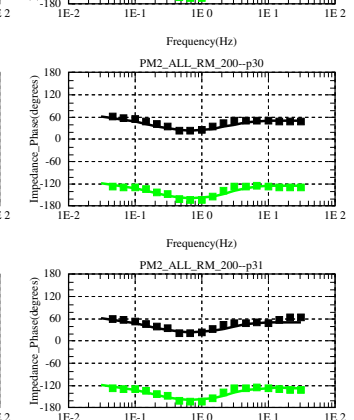

Frequency(H)

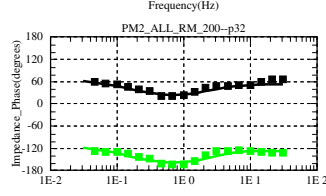

Frequency(H)

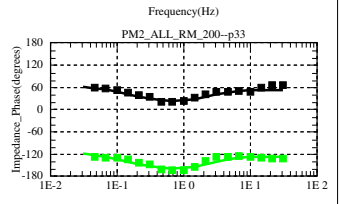

$\begin{aligned} \text { Frequency(Hz) } & \\ \text { PM2 } & \text { ALI RM 200- }\end{aligned}$

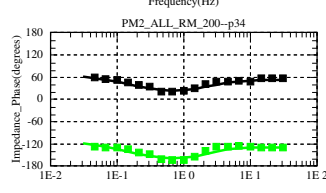

Frequency(H)2
PM2 ALL RM_200-p25

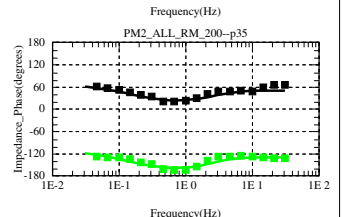

Impedance Phase

Figure A-1: Model fit (boxes) and field data (lines) of the apparent resistivity (left) and impedance phase (right) for Line 1. TM and TE modes are black and gray, respectively. 

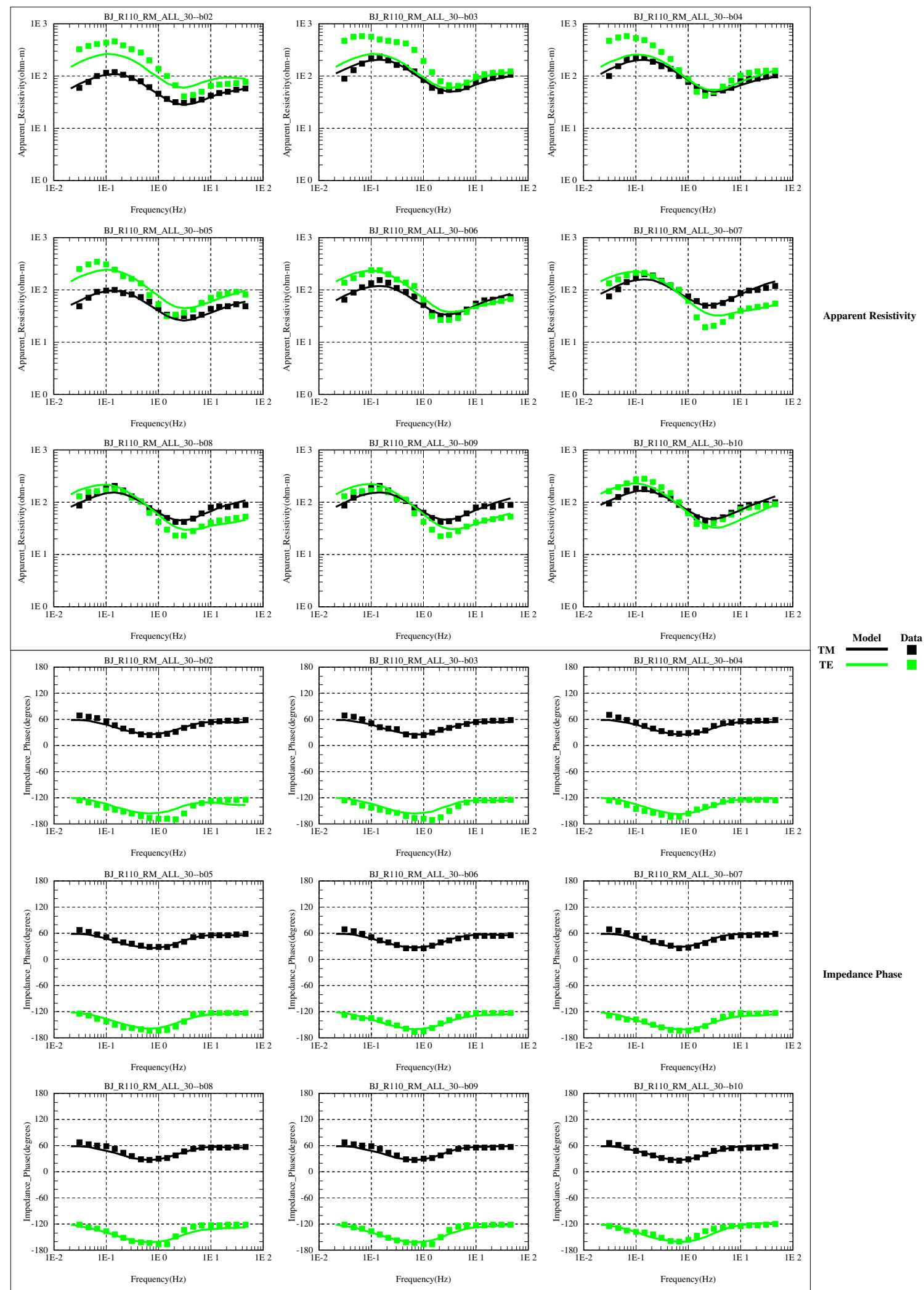

Figure A-2: Model fit (boxes) and field data (lines) of the apparent resistivity (top) and impedance phase (bottom) for Line 2.TM and TE modes are black and gray, respectively. 

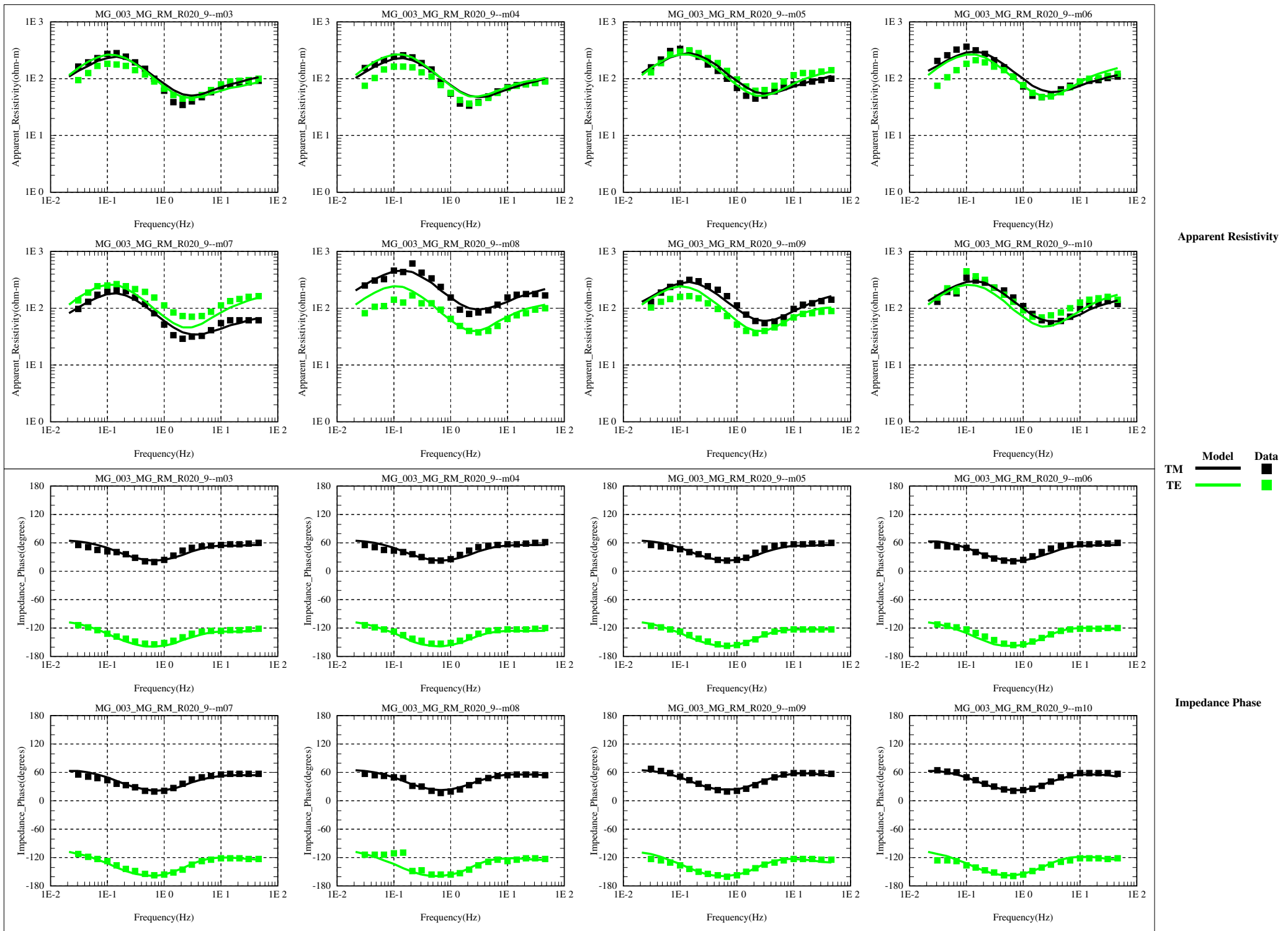

Figure A-3: Model fit (boxes) and field data (lines) of the apparent resistivity (top) and impedance phase (bottom) for Line 3.TM and TE modes are black and gray, respectively. 

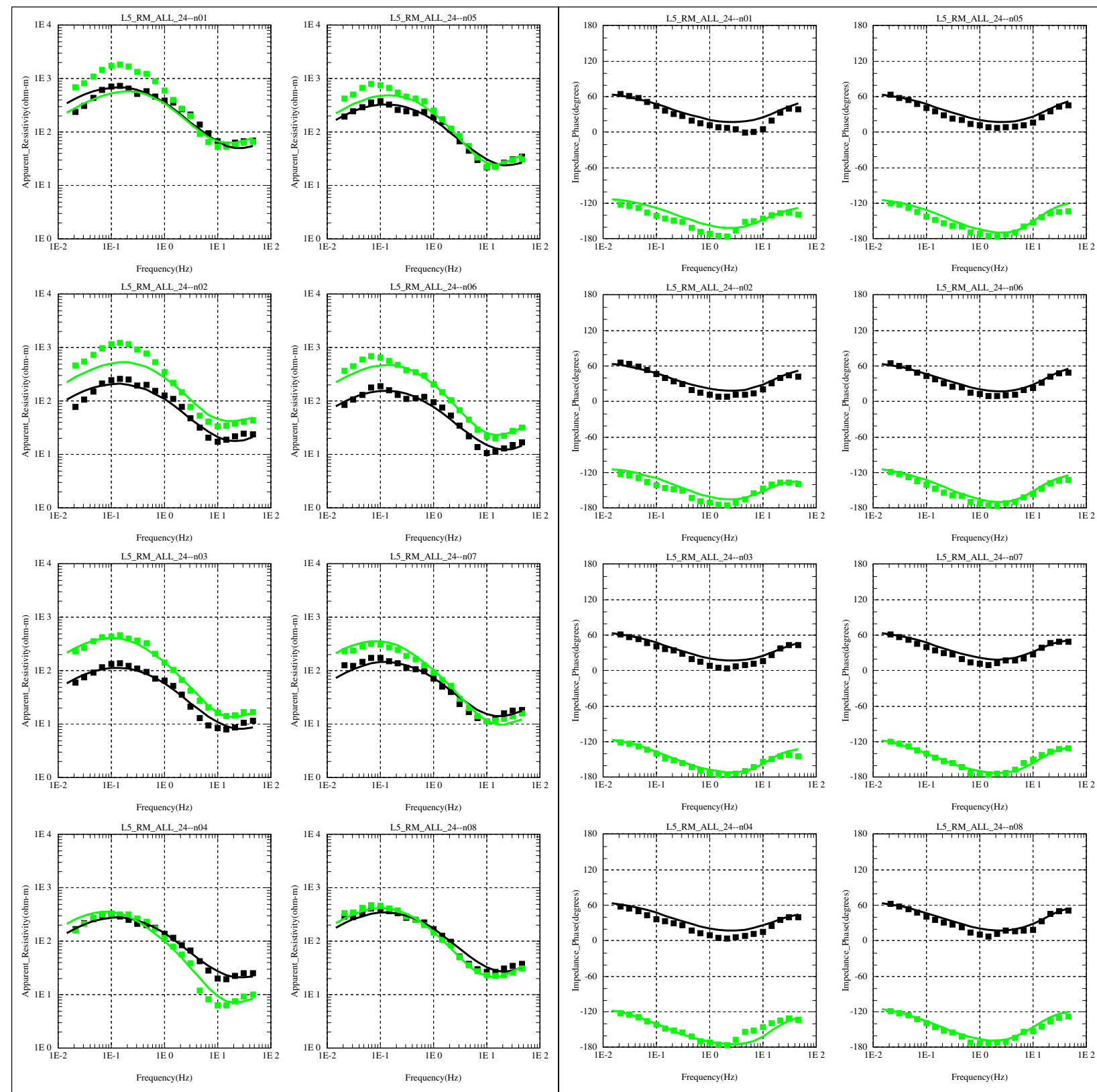

Apparent Resistivity

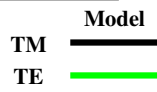

Impedance Phase
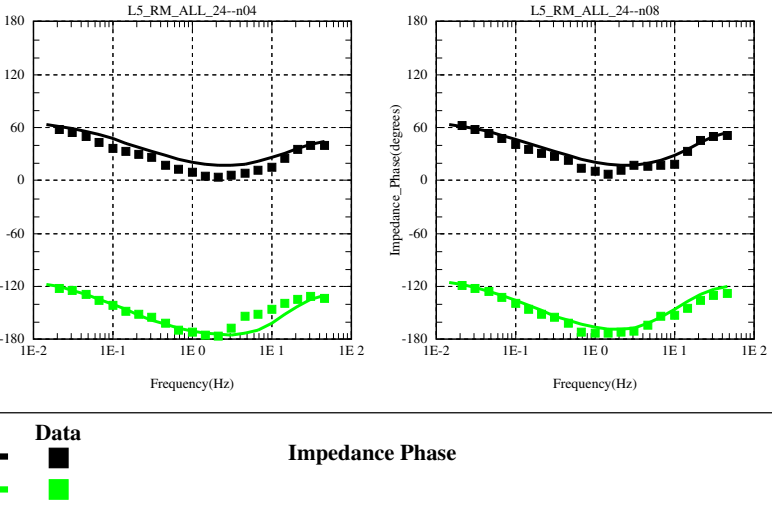

Figure A-4: Model fit (boxes) and field data (lines) of the apparent resistivity (left) and impedance phase (right) for Line 4. TM and TE modes are black and gray, respectively. 

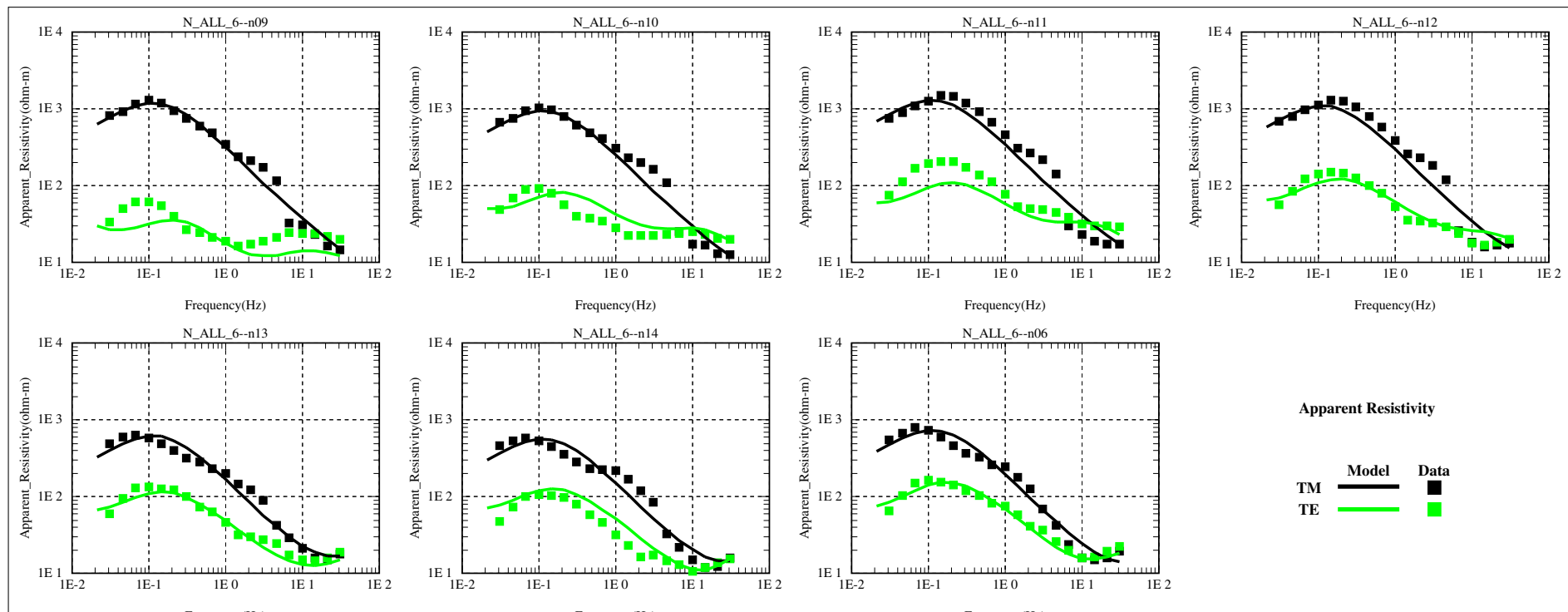

Apparent Resistivity
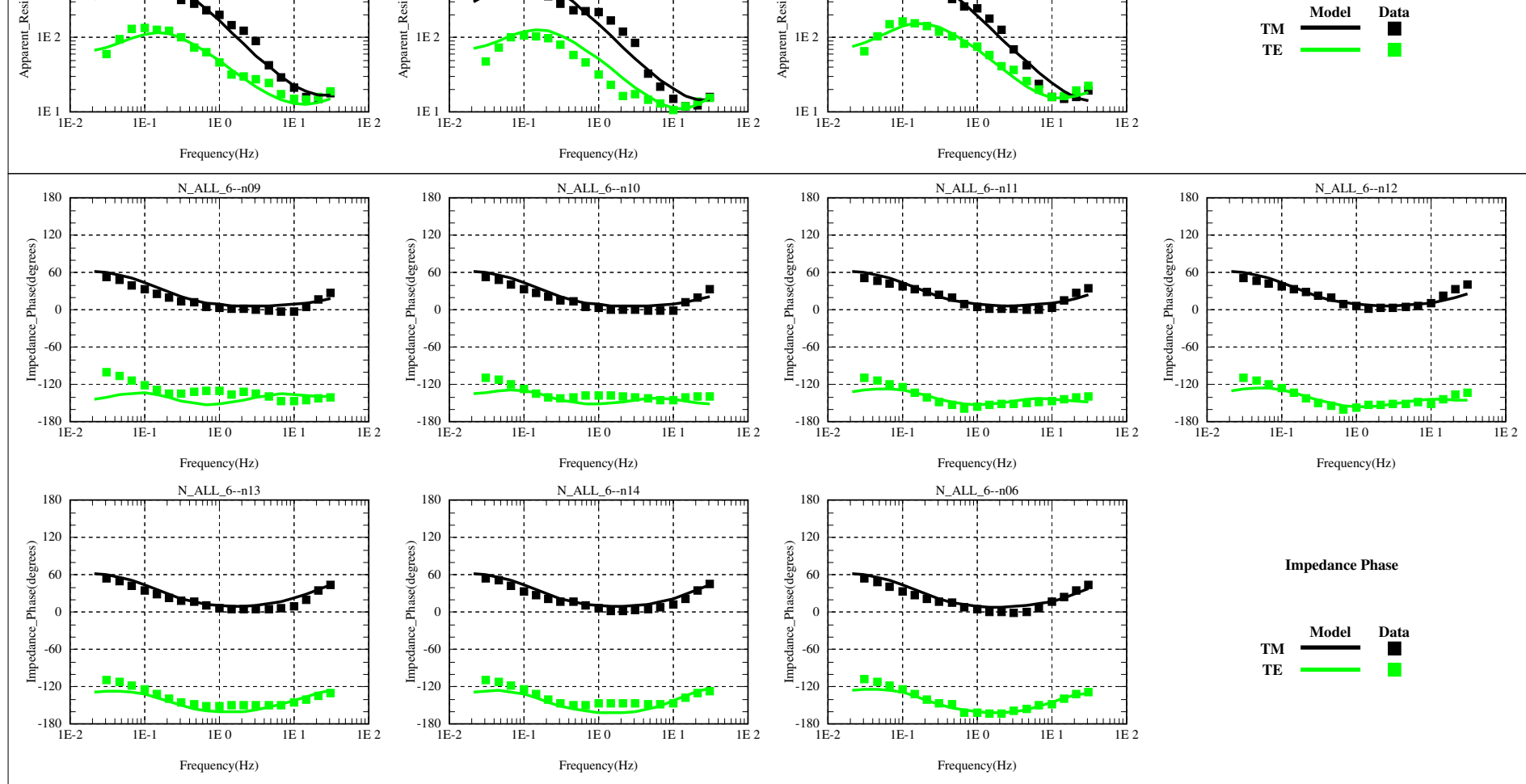

Figure A-5: Model fit (boxes) and field data (lines) of the apparent resistivity (top) and impedance phase (bottom) for Line 5.TM and TE modes are black and gray, respectively. 


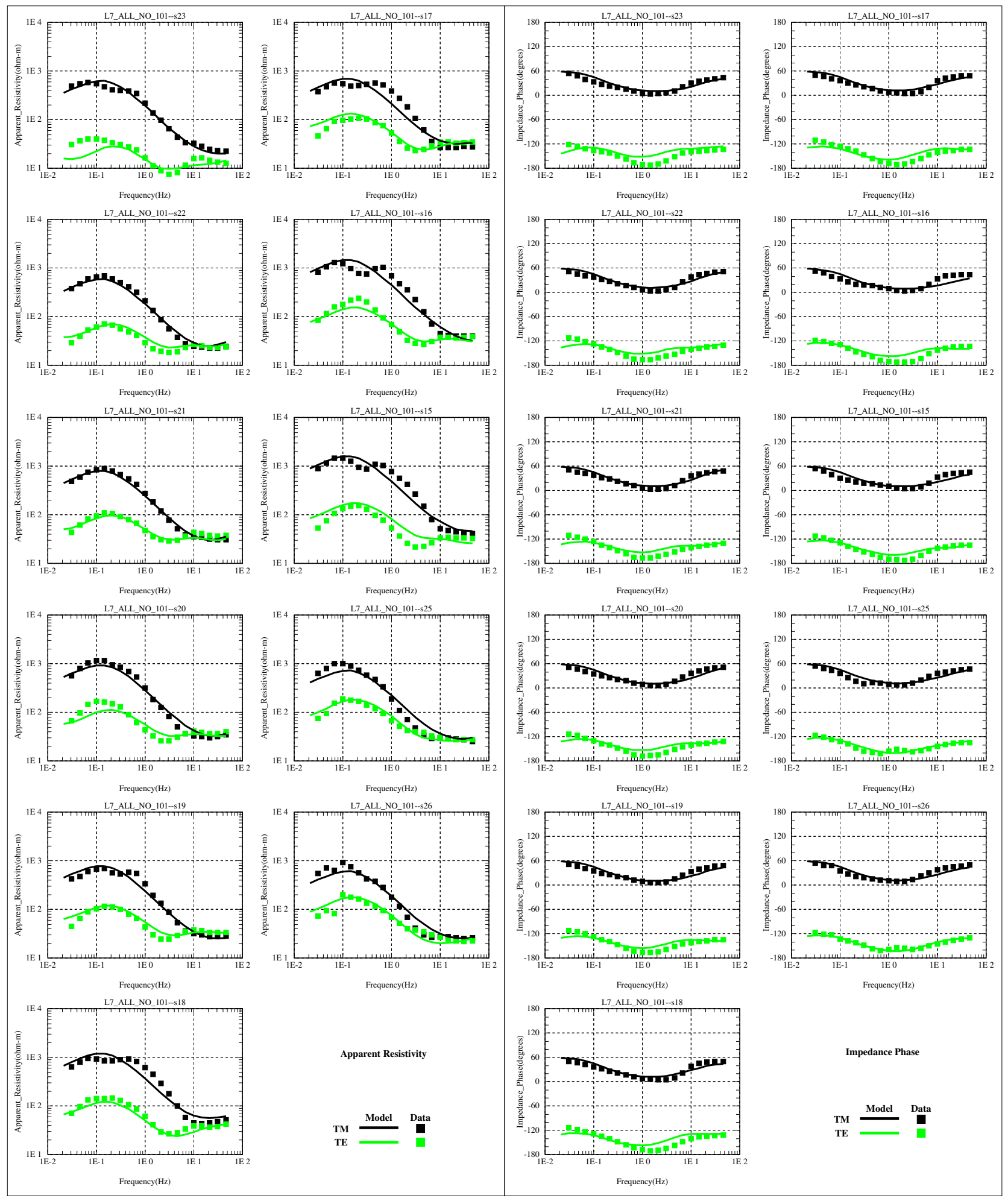

Figure A-6: Model fit (boxes) and field data (lines) of the apparent resistivity (left) and impedance phase (right) for Line 6. TM and TE modes are black and gray, respectively. 